Beliefs and Tales of San Cristoval (Solomon Islands).

Author(s): C. E. Fox and F. H. Drew

Source: The Journal of the Royal Anthropological Institute of Great Britain and Ireland, Vol. 45

(Jan. - Jun., 1915), pp. 131-185

Published by: Royal Anthropological Institute of Great Britain and Ireland

Stable URL: http://www.jstor.org/stable/2843390

Accessed: 21-03-2015 15:51 UTC

Your use of the JSTOR archive indicates your acceptance of the Terms \& Conditions of Use, available at http://www.jstor.org/page/info/about/policies/terms.jsp

JSTOR is a not-for-profit service that helps scholars, researchers, and students discover, use, and build upon a wide range of content in a trusted digital archive. We use information technology and tools to increase productivity and facilitate new forms of scholarship. For more information about JSTOR, please contact support@jstor.org. 


\section{BELIEFS AND TALES OF SAN CRISTOVAL (SOLOMON ISLANDS).}

By C. E. Fox and F. H. Drew. ${ }^{1}$

\section{CONTENTS.}

\section{PART I.}

\begin{tabular}{llllllll} 
1. Introduction & $\ldots$ & $\ldots$ & $\ldots$ & $\ldots$ & $\ldots$ & $\ldots$ & 131 \\
2. Figona (Spirits) & $\ldots$ & $\ldots$ & $\ldots$ & $\ldots$ & $\ldots$ & $\ldots$ & 135 \\
Tales of Figona $\ldots$ & $\ldots$ & $\ldots$ & $\ldots$ & $\ldots$ & $\ldots$ & 142 \\
3. Prayers and Charms & $\ldots$ & $\ldots$ & $\ldots$ & $\ldots$ & $\ldots$ & 151 \\
4. Ataro (Ghosts and Spirits) & $\ldots$ & $\ldots$ & $\ldots$ & $\ldots$ & 160 \\
Sacrifices and Shrines & $\ldots$ & $\ldots$ & $\ldots$ & $\ldots$ & $\ldots$ & 164 \\
Tales of Ataro (Ghosts) & $\ldots$ & $\ldots$ & $\ldots$ & $\ldots$ & 170 \\
Ataro (Spirits) $\ldots$ & $\ldots$ & $\ldots$ & $\ldots$ & $\ldots$ & $\ldots$ & 174 \\
& \multicolumn{3}{c}{ PART I. } & & & &
\end{tabular}

\section{InTRODUCTION.}

THE people of San Cristoval are closely connected in many ways with the people of Mwala (also called Mala, Malaita or Malanta), Ulawa, Ugi and south-eastern Guadalcanar (or Marau). Over all this area there may be said to be only one language, with four or five dialects, and a number of sub-dialects differing but little from one another. To the west another language, not very different in grammar, is spoken in Florida, Guadalcanar and Ysabel, while to the south-east, though at a considerable distance, the language of the Banks Islands shows many similarities. In this area of the south-east Solomons there seem to be no exceptional languages, and Lau, Saa, Wango and Fagani are types of the leading dialects. In physical appearance, too, the people are much alike, and distinct on the whole from the people to the west. In social customs and in the arts of life, as well as in their religious beliefs, the same similarity cannot fail to be observed.

While, therefore, we describe in this paper the beliefs of the people of San Cristoval, we shall illustrate the agreement of their beliefs with those of the Eastern Solomons, and to a much less extent with those of the people of the Banks Islands and the Florida Group.

Dr. Codrington has partially described these people in his well-known book The Melanesians. But he was led into two. serious errors as regards San Cristoval. He believed there was no division into exogamous clans with mother-descent, in parts at least, of San Cristoval ; and he denied the existence of the worship of spirits, considering that ghosts alone were the objects of worship.

1 The news of Mr. Drew's death in the Solomon Islands has been received since this paper was read. 
Thus he writes ${ }^{1}$ that there is one very remarkable exception in Melanesia to the general rule of division into exogamous clans: "it is not to be found in Ulawa, Ugi and parts of San Cristoval, Malanta (Mala), and Guadalcanar, a district in which the languages also form a group by themselves, and in which a difference in the decorative art of the people and in the appearance of the people themselves, thoroughly Melanesian as they are, can hardly escape notice. In this region, the boundaries of which are at present unknown, there is no division of the people into kindreds as elsewhere and descent follows the father. This is so strange that it seemed to me for a time incredible, and nothing but the repeated declarations of a native who is well acquainted with the division which prevails in other groups of islands was sufficient to fix it with me as an ascertained fact."

Again he writes" : "It would seem that the absence of exogamous divisions of the population in that region of the Solomon Islands in which descent follows the father (namely in Malanta about Cape Zelée, in Ulawa and in San Cristoval) must make the system of family relationship very different from that which has been described as prevailing in the Banks Islands and Florida."

And he even explains the existence of couvade in San Cristoval by this supposed absence of mother-descent there, couvade occurring "where the child follows the father's kindred." 3

In all this, misled by his informants, he could scarcely have been farther from the truth, at least as regards San Cristoval. In all the villages known to us, whether on the coast or in the interior, and certainly in the parts known to Dr. Codrington (Fagani and Wango), exogamous clans, generally in some numbers, with mother-descent, everywhere prevail, and form, indeed, the most outstanding feature of the social organisation of the people. We hope to return to this subject in a later paper; but Dr. Codrington's authority in such matters is so deservedly high, that it will be well, perhaps, to give at once some particulars in support of our statement.

At Bore, not far from the part of San Cristoval which Dr. Codrington knew as Arosi, there are now eleven exogamous clans: Atawa, Amwea, Araha, Aopa, Bora, Mwara, Amaeo, Urawa, Adaro, Kahuko, Mwa. Each clan (there called huo) has its burunga, its forbidden thing. ${ }^{4}$ For example, the Kahuko (owl) clan may not eat owls, because the woman from which the clan derives its origin, fleeing from her mother and climbing a tree, was there and then transformed into an owl. Bore may be taken as representative in this matter of Arosi, the same thing prevailing at other places, such as Heuru and Wango, where also the clans are called huo, and the forbidden thing burunga: each huo has its burunga. Occasionally, of course, marriages have taken place within the clan, but these have always been considered by the natives as unlawful marriages, and have involved either the death of the offending party, or the payment by him of a very heavy fine.

1 The Melanesians, p. 22.

2 Op. cit., p. $41 . \quad{ }^{3}$ Op. cit., p. 228.

${ }^{4}$ Like the buto of the Florida kema. 
Exactly the same state of things exists in the division of San Cristoval called Bauro. For example, at Rafurafu, within a mile of us, there were formerly, as the older people remember, eleven clans, kumu (corresponding to the Florida kema), the names being as follows: Atawa, Amwea, ${ }^{1}$ Uraua, Mwara, Adaro, Aopa, Pagewa, Fari, Kari, Kafiko, Araha. Here, however, all have died out except the first three. Here again each clan has its burunga, the same word being used as in Arosi. This state of things prevails at Fagani, Mwanihuki, Rumatari on the coast, and in the bush villages, and, in fact, everywhere where we have been able to make enquiries. The number of clans varies, the restrictions are different in different places, the physical marks of each clan are thonght to be everywhere the same. But nowhere is there father-descent and nowhere are clans absent. Needless to say, every native of San Cristoval is well aware of the name of the clan to which he belongs, for these divisions are the very foundation of his social system. Even animals are thought by natives to be so divided. For example, there are three mice clans recognised, the members of which are known by the way in which they nibble almonds, either at one end, or at the other, or in the middle, reminding us of one of the names of the Banks Island divisions, named at Mota "the one side of the house," "the other side of the house" and "the middle post," the last consisting of adopted children marrying with either moiety.

After becoming aware of the existence of clans in San Cristoval, we naturally enquired whether they exist also in Ulawa and Saa. The San Cristoval people, who frequently cross over to both places and sometimes intermarry, replied "Yes, the clans exist there just as they do here, and descent is reckoned from the mother." Several Ulawa and Saa natives denied this when asked, but further enquiry showed the information to be correct. A woman in an Ulawa tale was called an "Amwea" woman. A native of Ulawa who persistently denied the existence of clans there, was proved to belong to the shark clan, another to the adaro (akalo) clan, and so on, till no doubt remained in our minds that exogamous clans are the rule in Ulawa, and mother-descent general. The same is true of Saa, though the clans there have other names. The word for clan is komu, a word which in Florida means island or village; which is very like the San Cristoval name kumu. The reticence of the natives in regard to their clans is remarkable. When one of us first began to make enquiries in San Cristoval, a Wango native, educated at Norfolk Island, told him there were no clans at Wango nor motherdescent. Yet this native knew perfectly well the facts which he then denied, and had known from childhood to what clan he belonged and what food was forbidden to him.

The second error into which Dr. Codrington was led was that he considered the people to be ghost worshippers, but not spirit worshippers; they merely, as he thought, invoked and sacrificed to the souls of their dead ancestors, i.e., to ghosts (using ghost to mean a disembodied spirit, and reserving the term spirit for beings

1 Atawa and Amwea seem to underlie the other clans. 
who have never been men). In this he distinguished the religion of the Solomon Islands from that of the Banks. "Spirits," he writes, "have no position in the religion of the Solomon Islands, the ghosts are objects of worship." And again, "in the western islands (including San Cristoval) the offerings are made to ghosts, and consumed by fire as well as eaten; in the eastern islands they are made to spirits, and there is no sacrificial fire or meal. In the former nothing is offered but food, in the latter money has a conspicuous place."

In San Cristoval, however, spirits are worshipped as well as ghosts, and have sacrifices offered to them, money as well as food. In fact the worship of spirits may be said to be more complete than in the Banks Islands, as the stories of spirits given below and the account of the worship paid to them will show. But in this case it is not difficult to see how Dr. Codrington was misled.

In the first place all the hiona or figona of San Cristoval have a serpent incarnation, from Agunua the creator, worshipped by everyone, to Oharimae and others, only known to particular persons. These were thought by Dr. Codrington to be the only spirits believed in, although there are other spirits, called atairo, who might be incarnate in almost any animal. The Christian natives, however, with whom alone Dr. Codrington seems to have had any intercourse, had learned to associate with the devil a spirit with a serpent incarnation. They had been worshipping, as they supposed, the devil, and a feeling of shame kept them silent. They were of course quite wrong, as their spirit Agunua, who took the form of a serpent, was good, not evil. They had no belief, or very little belief, in any evil hiona. But the idea became firmly rooted in their minds that they had been worshipping the devil; and although the story of Genesis has never been translated into their language, the belief is now quite general, among heathen as well as Christians, through the spread of Christian teaching; and their reluctance to describe their worship of the serpent remains to this day. It has already led to a certain confusion in their minds, and is a not uninteresting example of the influence of a foreign culture on native belief.

But apart from this it appears clear to us that the cult of the serpent-spirits was already on the decline when Englishmen first came to San Cristoval. We believe that here we have the meeting of two cultures, one which we shall call the Figona culture, native and original; the other, which we call the Ataro culture, brought in from without and much later. We shall enter more fully into this below, but here we may note the evidence offered by the meanings of these two words figona and ataro as used by the people of San Cristoval.

The people clearly distinguish in their minds between a spirit and a ghost, but they have no words to express the two conceptions, their language in this respect being no better than English. A figona is a spirit and never a ghost, but it does not include all spirits. All figonas appear to have a serpent incarnation. An ataro means a ghost, but not only a ghost: among the ataro are almost as many spirits as ghosts. If figona worship were earlier and ataro worship had grown up later among the people themselves by a process of evolution, we cannot 
conceive such a use of terms. Ataro would have been restricted to ghost, since there already existed among them a word for spirit. But if the ataro culture came in from outside, then the word would already have its double meaning, ${ }^{1}$ and the result would be a confusion in native belief as to whether certain spirits should be rightly called ataro or figona, which is exactly what we find at the present time.

This touches the question, too, whether Melanesians believe in evil spirits. Dr. Keane has written that in Melanesia "there is very little true demonolatry. Dr. Codrington says none at all: 'It may be asserted with confidence that a belief in a devil, that is in an evil spirit, has no place whatever in the native Melanesian mind.' This seems to be stated rather too forcibly." Of San Cristoval it may be said that there is little belief in evil figona; there is a belief in evil ataro, both ghosts and spirits; but there is little sacrifice to ataro spirits, much to ghosts, and there are few prayers offered to the former, though there are plenty of charms to drive them away. But this belief, such as it is, in evil spirits, came in chiefly, if we are right, with the later culture: when the ataro landed, fear was multiplied sevenfold in San Cristoval religion. Belief in evil spirits is rather introduced than original. Nor did the people ever really learn to worship them as they did the ghosts: though from that time the woods and the sea have been haunted by such beings, ever on the watch to injure and destroy living men.

\section{FIǴONA.}

The word figona means a spirit. Elsewhere in San Cristoval figona becomes higona, hi'ona. In Florida to the west the word is again found as vigona, and it is not improbable that the Saa $l{ }^{\prime} \circ \alpha^{2}$ is a variant. At Ulawa the form is hi'ona. The apostrophe marks a break in pronunciation.

A fugona did not always have an incarnation. Very many pools, rocks, waterfalls or large trees were thought to be the abode of figona, but these figona were never seen. But the chief figona, who really received worship and sacrifice, had all of them a serpent incarnation, and so far as we know, no figona had any other incarnation, differing markedly from ataro in this, for the latter took freely the form of men, dogs, birds, snakes, trees or clouds. These serpent spirits could, however, take the form of a stone, or retire within a stone, and sacred stones seem to be connected with figona rather than with ataro.

It would seem that every spot where a man felt awe, such as a deep gorge, a waterfall, a dark pool, or a wide-spreading tree, was likely to become a dora maea or apuna, a sacred place, thought to be inhabited by a figona. Thus there is a large tree not far from Fagani where a figona lived. No offering was ever made there, no prayers were addressed to the spirit; but travellers would go silently

1 As, for example, atua in Maori.

${ }^{2}$ Wrongly spelt $7 i 0^{\prime} a$ in The Melanesians. 
past the spot, or speak in whispers. There is a deep river gorge near the inland village Raumae, and a figona is said to inhabit it. If a man ventures into the gorge, his soul (ataro mauri) may be taken captive by the figona, and the man on his return sickens and dies. He may, however, recover by the help of a sorcerer, who has power in sleep to send out his own ataro mauri and recover captive souls from the gorge, just as he sends out his soul in sleep to discover where things lost or stolen have been hidden. This figona seems to act like an ataro, and probably sacrifices are made to it. There is a pool near the source of the Wango river, deep and dark, surrounded by walls of grey limestone on whose ledges ferns cluster. This is the abode of a figona, and the traveller as he passes throws in a bit of bua (areca-nut), from which act the place is called Hau gasi bua, "the stone where one throws areca-nut." Passing this spot and crossing the low ridge of hills at the watershed, one comes to a steep descent, at the summit of which there is a prominent rock, called Hauroroboa, "taboo stone." Here the traveller plucks and places on the rock a green branch of ege (a shrub). As long as the branch does not wither, his feet will not grow weary, however long the way, but when the ege withers, the charm has lost its power. No prayer is said and no sacrifice made. It is interesting to compare similar practices elsewhere. There is near the top of the mountain at Mota in the Banks Group a spot where stones are piled together. Each visitor in turn takes a stone and adds it to the pile, first resting his hands on top, while his companion lays the stone on them, saying, "May your days in the world be many." Here, too, an overhanging creeper is twisted round the finger. Both acts are explained as a protection, the spot being sacred to a vui (spirit). The stone placed on one's hands holds one down in the world of the living. Dr. Codrington describes the same sort of thing, ${ }^{1}$ and mentions a case noted by Mr. Forbes in Sumatra, ${ }^{2}$ where the porters placed handfuls of leaves on a stone and prayed for a dry day and good luck; and again in Timor, where at the commencement of a steep and precipitous descent the natives laid leaves and twigs on a mound to ensure a safe descent, ${ }^{3}$ a practice very like that at Hauroroboa, and there connected with the presence of a figona.

But the principal figona are very different from these, and they have a serpent incarnation. There is one, indeed, who seems almost like a supreme spirit, called Agunua. It is hard to discover exactly what is meant by Agunua, whose cult was once widespread. Particular places worship particular serpents, or particular figona incarnate in serpents, but all these seem to be considered as local representations of Agunua, who, as one native said, is "all of them." The centre of the cult is at Haununu on the south-west coast; but though this is the cult of Agunua, there is a serpent at Haununu, to whom the actual sacrifices are made, who is called Kagauraha, and is in some way the representative of Agunua. Kagauraha is a figona, and is said to have created things; but Agunua is the creator. Almost

1 The Melanesians, pp. 185, 186.

2 Naturalist's Wanderings, p. 166.

3 1bid., p. 481. 
all of these local figona are represented as female snakes, Agunua as a male snake. The following is the story of Agunua as told us by some men of Ngorangora :-

"The centre from which the worship of Agunua spread over the island was Haununu. When nuts are gathered and yams dug, the first-fruits are taken and hung up in the gardens and in the houses; part is allowed to remain there and part is sacrificed to Agunua. With these are also placed awarosi. Agunua created all things - the sea, the land, men and animals, thunder, lightning, rain and storms, rivers, trees and mountains. When the time has arrived for the offering of the first fruits, the people place them ready, and wait for the signal from the priest at Haununu. On a certain day the priest, Haganihinou, son of Pwari, who was priest before him, takes the Haununu offerings and sacritices them to a real snake, a figona named Kagauraha. Then the people of Haununu perform the proper rites, and pass on the word to the next village by the sound of the drum. Suppose in this way word has come to Waimumura from village to village, night by night, till it reaches the other side of the island. The people of Waimumura have for some days been expecting it. Their offerings hang ready in their houses. Then the drum beats out the message, 'The Pwirisu (a rail) goes on to you at midnight,' i.e., the figona Agunua. Next day at evening each person in Waimumura, man, woman and child, takes a dracaena leaf and sets it up in his doorway. They then drum on the message to the next villages up and down the coast, 'The Pwirisu goes on to you at midnight.' Then they lie down each on his sleeping mat, and wait for the first cock-crowing. When the cocks crow everyone rises, takes his dracaena leaf and sweeps the house, sweeps the beds, the platforms, the cooking vessels, and everything in the house, saying as he does so a Haga-rahe, a prayer :-

Agunua!

Take thou away fever and ague,

Take thou away headache,

Take thou away thieving,

So that our bodies may be light.

Take thou away a bad season, bring in a good.

Keep my feet when I climb an almond tree lest a branch break,

Keep my people when they climb lest any fall,

Preserve the taro so that when planted it may thrive,

And the banana that it may bear good fruit,

Let none steal from my garden, none steal my pigs,

May the pigs increase; preserve the dogs.

Then all go outside, each carrying his dracaena leaf; no one must remain in the houses, but all, men and women, children and cripples and sick folk, go together to the sacred grove near the village, sham fighting as they go; for besides the dracaena leaf each man carries his weapons, and the women and children carry 
Kafits (a tree with dry wood used for making fire) to rub fire for the sacrifices. So they go fighting and singing, and the words of the song are these:

The almonds shall ripen,

The pigs' tusks shall curl.

When they come to the sacred grove each plants his dracaena leaf in the ground, and they stand round the central tree, and one of them builds a platform of twigs and burns sacrifices of pudding, made from the first-fruits, and they all say aloud to Agunua, 'Do thou remain here: when a man shall come for thee from yonder (pointing to the next village), go with him on thy rounds till thou comest again to Haununu.' Then they put a creeper by the tree, so that in that year all creepers by which men climb may be strong and hold them securely, being blessed by Agunua, and they put a stone to represent puddings, so that Agunua may bless all the cooking in that year, and a crooked stick to represent adzes for cutting down trees, that wood-felling may prosper; and they take a small stick and thrust it through a dracaena leaf, and bend the leaf over to represent a house, that Agunua may bless all craftsmen who build houses in that year, and a pandanus leaf to represent mat-making, and so all these are blessed by the figona. Then they return to their village."

This ceremony takes place once a year, and everyone in the village must take part in it.

Agunua created men. He created a woman, who, when she became old, went one day to change her skin in the stream, for that was then the custom. She had a daughter whom she left in the village. When the old woman had changed her skin she came back, looking young and lovely once more, but her daughter said, "This is not my mother, this is a strange woman," and would have nothing to do with her. So the old woman went back to the stream, but the water had carried away the old skin, and she wandered some way down the stream before she found.it, where an eddy had carried it against a bough overhanging the water, on which it stuck. She put on the old skin and returned to her daughter. "Now I know you," said her daughter; "you are my mother." And so death came into the world, because the child cried and did not know her mother. Otherwise men would always have changed their skins when they grew old.

The same story is told in the Banks Islands of Iroul, the grandmother of Qat; and in Florida of Koevasi, who is said to be superhuman. The stories are exactly alike, even in details. According to the Banks Islands story, the child who cried would be Qatgorosom, Qat's mother. The connection with a serpent explains the change of skin in the Banks Islands story, where no serpent is mentioned.

There is another story not told of Agunua, but of Kagauraha, Kahausibwari, Kahuahuarii, and other local representatives of Agunua, all of whom were figona, and female snakes; and this story has also its parallel in the Banks Islands. The story varies in details in different places, but is in substance as follows :- 
One day, the daughter of Kagauraha, who had grown up and married and had a boy, left her boy in charge of his grandmother the serpent. The boy's father did not know of this and was away fishing for bonito. Kagauraha coiled round her grandson and he lay on the coils, but began to cry. Kagauraha said to him, "Grandson, I have no legs : I can't stand up and nurse you." While the child was crying his father came in and seeing the serpent strangling his son, as he supposed, he chopped it up with a knife. But as he chopped it up, the severed pieces reunited. At last the serpent could stand it no longer, but went off, first to the island Ugi, seven miles from San Cristoval, saying as she went, "I go, but now your crops will fail." And that year there was a famine, all the crops failing as had been foretold. When Kagauraha reached Ugi she climbed a tree, but she could still see her home, so she left Ugi and went on to Ulawa, and then to South Mwala. But she could still see her home (various places on the north coast, different in the different stories). She then went to South-east Guadalcanar, Marau, but after a time swam down the south coast of San Cristoval to Haununu. When she got near Haununu she saw two boys in a canoe, who were alarmed and called out, "You are an ataro and will eat us." Said Kagauraha, "It is you two who are ataro, I will do you no harm." So they took her home, made a temple, and there she has lived since. She took a yam with her, and gulped this out of her mouth at Haununu, and from this came all sorts of yams.

The Banks Islands story is as follows: A woman who was descended from a large snake, married a man and they had a child. The man used to go out fishing, and the woman to the gardens, and she used to leave the child in charge of her grandmother the snake, of whose existence her husband was ignorant. One day the man came home and found the snake nursing his child. Surprised and angry, he scolded his wife, who confessed that the snake was her mother. He watched his chance and one day when his wife and child were away, he set fire to the house in which the snake lay and burnt it to the ground. The wife came home and the snake's head spoke to her, "I die, but bury me yonder, and what comes up will be me." So the woman buried the snake and fenced in the spot, and a coconut sprang up there. After a time the first nut was formed, and one day when the man went fishing, the woman noticed the nut. It was a drinking nut and she plucked it and said to her son, "This is your grandmother," thus explaining the eyes of the nut. When she opened it the milk spurted up, and fell on the face of the husband fishing in his canoe far away. He thought it was sweat, but as it ran down his nose he tasted it, and cried, "This is something new." Then he went home and said: "What have you two been eating?" They gave him the nut and he drank it and said: "This is what fell on me in my canoe." Said his wife, "Do you know that what you are drinking is my mother's blood?"

The first drinking nut from a coconut tree is sacred to Agunua, and the milk is poured out as a libation in the sacred grove. Many stories are told of Agunua. He was thirsty and rain fell to assuage his thirst. This was the origin of rain. A flat circular valley near Mwanihuki is called "Agunua's oven"; a winding river, Waiatana, is said to wind because Agunua lay there to rest, and the ground was 
marked with the impress of his coils. The way in which Agunua created things was as follows: He had a twin brother who was a man, and one day he remarked to him, "Here have we been a long while, and there is nothing yet to eat." Presently the man saw the serpent with a yam on its head, and the figona said to him, "Plant. this for food for my children and let the garden which you make be a large one." But the man replied: "What is the use of clearing a large garden for one small yam?" "Never mind," replied the figona, " make a large garden and try planting the yam, and if the garden is too large you can come back and tell me." So he took the yam and made an immense garden, but he had nothing to slice up the yam with. The figona gave him a shell and he cut up the yam and put the pieces in a basket and began to plant. He kept taking out piece after piece, but the basket never emptied: there were always as many pieces as before. After a time the garden was all planted and he waited for the yams to come up. When the shoots appeared, he found there were all kinds of yams, large and small, red ones and white ones, smooth and prickly, wild and cultivated, and also bananas, coconuts, almond trees and fruit trees of every description. "But," said he, "these are all too hard to eat, how am I to make them soft?" The figona gave him his own staff and said, "Rub on this and see what happens." This was the origin of fire and of the art of cooking. Then he cut up some yams and baked them over the fire. Some he did not look after : they were burnt, and this is the reason why some fruits are uneatable : they came from the pieces he burnt. Some pieces he didn't bake, and hence came wild taro and bananas and other wild things. Other pieces he partly burned, and from these came almonds and other trees, of which some fruit is sweet and some bitter. "Well," said the man, "now I have all food that I need, but how am I to cut a tree to make a food bowl?" The figona gave him a stone and told him to tie on a handle with creepers; from this came adzes, and he cut down a tree and made a bowl.

When all things were ready the figona bore a child, who grew up to be a man, but he was helpless in such matters as cooking, making a fire, and weeding a garden. When the figona saw this he gave birth to another child, a girl, who grew up to be a woman and understood these matters: "Be it your part," said the figono. to the woman, "to get food and prepare it by cooking and distribute portions of it." And so it has been ever since.

The chief sacrifice to Agunua was the one described as occurring once a year at the sacred grove at early dawn. But people also sacrificed with shell money, and by burning pudding made of yams and almonds in their own gardens or separately at the grove. Also prayers were frequently made to the figona as well as to ataro to restore health to a sick man, or to give rain in a drought, or to increase the crops. No doubt there was some confusion with prayers to ataro. At the great annual sacrifice described, sacrifices were offered to ataro, especially to those incarnate in sharks, after the completion of the sacrifice to the figona, usually on the following day, or even on the same day; but nothing could be sacrificed to an ataro till the rites connected with the figona had been performed. 
There seems to be some reason for thinking the cult of Agunua to have been much more widespread in the past than it is now. The people themselves say it was once all over the island, the drums, carrying the message rapidly to all parts. In a letter written in 1856, Bishop Patteson mentions the serpent worship. "Is it not a significant fact," he writes, "that the god worshipped in Gera and in one village in Bauro is the serpent!" By Gera is meant, no doubt, Marau Sound in South-east Guadalcanar, a district with which the Bishop was well acquainted, and by Bauro probably Arosi, at the north-east end of San Cristoval, from which he had obtained boys and where he was well known.

In $A$ Naturalist among the Head Hunters, Mr. Woodford tells how one morning at Aola, on the north coast of Guadalcanar, "the whole village turned out to sacrifice to the tindio presiding over the Canarium nut, or Solomon Island almond. The almonds had been ripe a week, and I had expressed a desire to have some, but my boy, Hogare, had informed me that it was quite impossible to have some until the offering to the tindio had been made." Mr. Woodford then describes the proceedings. They all went down to the sea shore, and "a space was swept clean beneath the spreading branches of a Barringtonia." They then made little altars of dry sticks, and first-fruits were sacrificed, fire being made by rubbing. This so much resembles the sacrifice made to the figona that we would suggest it really was the same. Tindio, or tindao, is the equivalent, however, of the San Cristoval ataro, not figona. But in San Cristoval sacrifices were sometimes made to the ataro practically at the same time, as soon as the figona rites were concluded, and Mr. Woodford may easily have failed to hear any mention of the former ; or possibly the tindio had really displaced the figona in that part of Guadalcanar. At all events, if not now the same thing, it appears to be a survival of the figona cult and an evidence of its former extension.

A native of Ulawa informs us that, in ancient times at any rate, the worship of Agunua was practised in Ulawa. It was still practised when the islands known as the Three Sisters were inhabited by natives. These islands are half-way between San Cristoval and Ulawa, and it was the practice in those days, we are told, for a party of natives from Ulawa to paddle over to the Three Sisters and wait there for tidings from Haununu. In the meanwhile a party from the Three Sisters had gone over to San Cristoval. When the worship and sacrifices began on the San Cristoval coast, these men brought the news to the Three Sisters, whence it was carried on to Ulawa by the party who were waiting. When Mendana discovered the islands in 1567, they were inhabited. Surville saw them in 1769, but whether inhabited or not we do not know. When Englishmen began to know them about 1850, they were uninhabited, and had long been so according to native acounts.

If, as we suppose, the figona worship was already waning long ago, driven out by the newer worship of ataro, introduced by foreigners, then the discovery by the natives that in worshipping the serpent they had been worshipping (as they supposed) the devil, merely helped forward its extinction, and made them reticent in speaking of their former beliefs and practices. 


\section{Tales of Figona.}

1. Wanimaniaru and Waniwagawaga.-The people of the village were afraid that Wanimaniaru and Waniwagawaga would kill some of them in revenge for the waste of their yams, which the people had thrown at one another in a sham fight. Then the spirit Agunua brought on a famine to punish them, and they all went to Kufe, inland, all except those two, that is; they still remained, but grew weak with hunger, eating a pig and nuts only. But the spirit pitied those two, and let them have again the food that grows in the gardens; so that Waniwagawaga saw one day yams shooting up at the door of his house, and, taking stakes, he twined his yam vines round them; and at the same time Wanimaniaru saw taro springing up, and he fenced it round. When the yams and taro came to maturity, the two made puddings of the roots, and they sacrificed to the spirit; and they worked together in their garden, and found the food very plentiful. Then their people noticed the garden and came back from Kufe, inland, to those two men, and when they came near they asked them, "Are you two still alive?" "Yes," said they, "we are still alive"; and their friends said, "But what have you had to eat to keep you alive like this?" "Oh," said they, "nothing but a pig and nuts: Waniwagawaga killed the pig and cut off its head and gave it to Wanimaniaru."

2. Karamunagau.-The serpent Karamunagau came at first from an island in the open sea to a village called Fafara, near Rumahui, on the north-west end of San Cristoval. Her head reached the shore and told them to make for her a house, tall and long. When the people had made the house the serpent landed and coiled herself within it. She told them to go and mark out a garden, but when they had done so she was not satisfied, as the garden was too small. They therefore marked out another. This time she was pleased, and told them to cut down the trees. When the trees had been cut down and the fallen timber burnt, the garden was spaced out with lines of logs, and then a charm was uttered over the stakes up which the yam vines would run, and another for the stone axes with which they were cut. Then the garden was planted with yams, which in due course sprouted, were staked up, grew to maturity and were dug. A small yam was first dug and put in the house sacred to the serpent.

After this she told them to go and look for opossums; only the male ones were to be eaten. Soon the people of the village were plagued with sickness, which was inflicted on them by the serpent because it desired to eat the flesh of a pig and no pig had been offered. They sacrificed a pig and all recovered. At another time a number of them fell sick because no shell-money had been offered. Those who refused to sacrifice any died. About this time the people got tired of the serpent and told her to leave them. She went south-east to Mwanigatoga. When she reached this place she said to the people, "I come here to dwell among you, but I bring with me no sacrifices." Until this time the people of Mwanigatoga had not made any sacrifices for the fruits of the ground, but the serpent told them that 
henceforth they must do so before any of them ate their yams or taro. "Don't take your yams and taro without giving thanks," said the serpent; " but do as I tell you and sacrifice to me." The people, however, had no wish to make sacrifices of firstfruits to the serpent, and told her she might go to some other place. "I go," replied the serpent, "but remember I have begun among you this practice of sacrificing the first-fruits of your gardens." She then swam out to sea, swimming with her head and tail out of the water. On that day there was only one man in the village of Haununu ; the rest had gone up into the bush to work in their gardens. This man looked out to sea, and saw the head and tail of the serpent standing up out of the water like an enormous tree. Those in the bush hurried down, but meanwhile the serpent had landed at the point called Mararo and the solitary man in the village advanced trembling to meet her. "Fear not," said the serpent, "but go and look for a place where I may dwell." He showed her Wainaou and she told him to build her a house there. The rest of the people were afraid and wished her to go away, but she said to them "Fear not, my children, I am your mother." While she lived here she gave birth to two young serpents, the first a female named Kafinuagigisi and the second a male named Finuagigisi. The people of Bofarito, an inland village, now claimed the serpent, as the man who had welcomed her to Haununu was really a bushman, a native of Bofarito. So there she went and there she remained, but of the people who sacrificed to her there, only two remain, and the rest are all dead.

3. Hatoipwari.-This serpent came from Marau Sound to Ngongo near the south-east point of Marou Bay. Here he made his home. His coming took place in this manner. A certain woman went one day to the reef gathering food, various kinds of shellfish. She saw a stone coming in on the waves, and the surf threw it close beside her. She picked it up, without taking any particular notice of it, but thinking it a good stone for cracking shells with, and she put it in her basket. After a time she went back to the shore and began looking for a stone to crack her shellfish with, forgetting the stone which she had put away in her basket. Presently however she remembered it, and sitting down by a large flat rock, she took out the stone which the waves had thrown at her feet and lifted it up to crack her shellfish; but as she held it up in the air, flashes of lightning darted backwards and forwards between the two stones. "Awii !" cried the woman; "what have I got here I wonder?" and she held up the stone once more, and once more the lightning flashed back and forth, and thunder muttered between the stone in her hand and the rock below. "Ah," she said, "thunder and lightning, this needs looking into;" and she put the stone away carefully, wrapped up in a pandanus leaf. Then she packed up her shellfish and set off home, and when she reached the village, she gave the strange stone to her father, Teheraha, and told him to examine it. He took it from her and placed it in a cave in the middle of a row of other holy stones and offered ura'i, i.e. money of dogs' teeth and porpoise teeth and strung shells. He slept and dreamed. He dreamed the stone came to him and spoke with him, saying, "I am the bearer of news. My father, a serpent spirit, is coming hither. The people of Hunganaibwari have driven him away from the place where he formerly 
dwelt. He will soon be here." He woke from his sleep and prepared a pig for burnt sacrifice. While he was doing so the people saw birds hovering in a flock round something far out to sea. They took a large canoe and paddled out, and as they paddled out the flock of birds drew nearer and nearer to meet them. Presently they saw a serpent floating in the water. They came close to it and their canoe was made to rock violently. "What can you be?" said the people, and they got its head into the canoe and so paddled ashore. When they landed the people came running, and said, "Put the whole of it into the canoe." They got it all into the canoe at last, and carried the canoe in triumph to the men's house and left it there that night. Next day they transferred it to a cave and then began offering their first-fruits to it. When they offer they take first some fruit of the ahuto tree, the tree with which fire is made by rubbing, and this they tie up in the mouth of the cave. If any of the fruit fall it is a sign that someone will fall that year in the nutting. Every year too they bring a small yam, but no nuts, for which the ahuto fruit is substituted, as that is also used for making fire. Prayers are made to the serpent by the people and their neighbours.

4. Kagauraha.-Kagauraha is a female serpent worshipped at Haununu. She and her numerous brood live in a house erected for them, at one end of which is an enclosure, within which is a hole in which the serpent lives. On the walls of this house are native carvings of sharks, frigate birds, and the turtle with a bird's head which causes earthquakes. Only certain men can enter the house, all old men. They enter to sacrifice and to ask the will of the serpent about any matters of importance. When they go in they bend low with hands spread out before them. The serpent asks for what she wishes, sometimes a pig and sometimes a human sacrifice. If anyone is ill it is a sign that a pig is desired and the person who is ill pays for it. A portion is given to the serpent and the rest is eaten by the worshippers. When a young coconut bears its first nut, the milk is drunk in the house in the presence of the serpent, after which men may eat and drink the nuts of the tree. When the first yams are dug some are sacrificed to the serpent, and other sacrifices are made when the gardens are planted. If they wish to know whether to go to war or not, the priest takes strips of dracaena leaves warmed over the fire and pulls them apart in the presence of the serpent. If the strands break they refrain from war. The breaking of one strand means the death of one man. A sign of anger is the swelling of the serpent. This takes place for example if a woman approaches, and was very marked when a missionary landed and asked for a school to be built there.

5. Bonguru, "Pig-who-grunts."-This figona lives in the forest. If a man walking in the forest hears near him what he supposes to be a pig grunting, and says to his companions " There's a pig, do you hear it grunting?" then in a moment he is surrounded by snakes : snakes in front of him, snakes behind him, snakes on either hand, and snakes in the air above him. This is because the figona has an objection to being called a pig.

6. Owaroi.-There was a certain man named Oharimae who sacrificed to figona, 
and there was another man named Ohimae who was eaten up by these figona. $\mathrm{He}$ was throwing away the entrails of a pig, and the entrails changed into snakes and ate him up, and when they saw he was already dead, they carried him (sic) to a village called Funarafa and left him there. There was another figona named Owaroi, and all the figona went to another village called Pagoki, and when they reached the place they saw at the door of a house a very large dark green stone, and they carried it back with them to a place called Narafa, to the man named Oharimae who sacrificed to them.

7. Faufonofono.-There was a woman living at Paone in Ugi, and one day she went into the forest with her child. Towards evening she was returning when she saw a figona. She had sat down to rest on the path and took some cabbage out of her bag and put it on a stone which she had found and placed on the path. The stone thereupon changed into a snake which rose up fold on fold, taller and taller. The figona told the woman to go away, but she refused, and watched the snake gliding across the path, fold on fold, and there the woman sat from sunset to midnight, by which time it had crossed the path. The woman then returned home and her child died.

8. Kapvaranaitira and Kapwirona.-These two figona had a dispute as to which was the taller. Kapwaranaihira stood on her tail and rose up fold on fold, but failed to touch the sky. Said Kapwirona, "You are standing on a hill, and here am I at the bottom of a valley, and yet you can't reach the sky." Whereupon Kapwirona stood on her tail and rose fold on fold, reaching to the sky and down again to the earth and up again to the sky.

9. Kafiomwapuru.-Kafiomwapuru was a huge man-eating snake who lived underground. The entrance to his lands was a deep hole with steep sides, which was once covered up on top. Once upon a time there were two brothers who stole some yams from the gardens of the people of their village. They decided to plant these yams at the mouth of the hole, not knowing of its existence. So they took two yams and planted them as they had planned at the mouth of the hole by which one went to the home of the snake. One day the two boys went to see the yams they had planted and found them already grown up and ready to dig. They were surprised but rejoiced and ran to get sticks for digging up their yams. But as they began to run the hole suddenly opened its mouth and the boys fell down and down, down and down, past walls of rock, till they came to the land underground where the man-eating snake lived. The mouth of the hole meanwhile closed up again above their heads. The two boys walked on till they came to a town, but it was deserted and overgrown with grass, with young trees already half-grown, only they could see that once there had been a town there. Then they went on once more, and after a time they came to another town, which also was deserted, but the posts. of many of the houses were still standing, and the grass and trees not yet grown up. When the two brothers saw the posts of the forsaken houses they became very sorrowful, thinking of their father and mother and friends. However, they went on till they came to a third town, and in this one not only were the posts of the

VOL. XLV. 
houses still standing, but even the rafters, and nothing was decayed, for though the great snake had eaten all the people there, it had only done so a short time before. However, the two brothers went on till they came close to the home of the snake, and here they paused for fear of him, thinking he would be sure to eat them also. But the elder said to his younger brother, "Come on, don't let us be afraid of him," and they went on till they came to the snake himself, and the snake was asleep. But the smell of the two boys came into its nostrils, and it woke up and saw them standing near it. "What do you come here for?" said the snake. "Our people deceived us," replied the boys, "by planting yams at the mouth of the hole, so that we might fall down it and be eaten by you." But the snake said, "I shall do you no harm, only you must work for me and plant my gardens." Then the two boys felt light-hearted and stayed and worked for the snake as he told them. They planted coconuts for him, and yam gardens, and taro gardens. They worked very hard, especially at the taro gardens, doing all the snake bade them. After they had worked a whole year the snake gave his daughter in marriage to the elder. After they had worked five years for the snake in this manner, he said to them one day, "Do you still think of your friends and wish to see them again?" "Yes, indeed," replied the boys, "but how are we to climb up again to our country above?" However, the snake said that if they wished to go back they might do so, and they begged him to tell them how. "Well, I will tell you," said the snake, "but you must do exactly as I say," to which both the brothers agreed. "Gather together into a heap all the taro you have planted," said the snake, "and take five thousand roots from each garden." This they did, all three working very hard, till they had heaped together five thousand roots from each garden, a very great pile. "What next?" said the brothers. "Make a platform," replied the snake, "and put the taro roots on it." So they made a huge platform and piled the taro roots on it, and said to the snake, "What next?" "Get up on top, the three of you, and all your pigs," said the snake. So they climbed up and sat on top, the three of them with all their pigs, and they called out to the snake "Here we are on top and what is to be done next, the platform is too heavy to move." But the snake replied, "Never mind, sit down firmly, the three of you and your pigs." Then he came under the platform and put his head to it, and stood up on his tail, and lifted them up and up, higher and higher, till they came out above ground again. Then the snake returned to his home, and the brothers ran to theirs. But one of them went first to tell the news, and when he got to the village he said to the people, "Come all of you and carry hither the taro my brother and I have brought back." So all the people of the place went to the platform and carried the taro, going backwards and forwards, but there was so much of it, that before they reached the last roots these had already grown rotten. Then the people all rejoiced at the return of the two brothers and beat all the drums, and blew upon the conches and played all the pipes, and made a great feast for them, and invited the people of neighbouring villages, saying, "Come and rejoice and feast with us to the two who have come back alive again." So everybody came and the pigs were killed, and the taro and 
yams were cooked and they all feasted together; and the two brothers related the story of their wanderings, until at length when the feasting was over the visitors returned to their homes.

The snake Kafiomwapuru is not called a figona, but merely " a snake"; but it is difficult to see much difference between it and Faufonofono for example. To sum up the matter, there seems to be one figona superior to the rest, called Agunua, to whom once not only all the island, but people farther off also, sacrificed and prayed. But there were many local figona incarnate in serpents, representing Agunua to the people of that particular place. These too had prayers and sacrifices made to them. Besides these, many a deep pool, large rock or tree, stream and waterfall, contained a figonc. People would sacrifice to these if they passed near, and pray to them. At Valuwa in the Banks Islands there is a deep hole, Dr. Codrington writes, "into which no one dares to look; if the reflection of a man's face should fall upon the surface of the water he would die; the Spirit would lay hold upon his life by means of it." So if a man approached the gorge of the Wairafa River in San Cristoval, the figona there would take captive his soul. But these figona were not evil ; it was the man's own fault, he had treated carelessly a sacred place. People fell ill too if the serpent figona were not satisfied with the sacrifices; but the figona were not feared like ataro. An ordinary snake was always killed when found in the gardens. All figona were spirits, never the ghosts of the dead; they were not usually seen ; they were connected with remarkable stones, and contained in them ; their incarnation, when they took form, was a serpent.

10. To conclude, we give a story of a snake figona from Mwala. It was told by an old man named Walakalia of Langalanga, on the west coast, in sight of both Boromoli in Florida, and Marau Sound in Guadalcanar, as the story tells. This is the San Cristoval story of Kagauraha with considerable variation, and it is known in South Mwala and Ulawa. It is particularly interesting as showing the extension of the serpent cult to North Mwala and Florida; and as definitely connecting that cult with the pirupiru, the sacred grove. Wherever the snake landed, there was a pirupiru afterwards. According to the story a pirupiru was founded in this manner at Marapa in Marau Sound, South Guadalcanar, and at Boromoli in Florida. In the story eight seems to be a charmed number. The serpent's name is " Eight fathoms." She comes to life after eight days' rain. She makes her house with eight leaves. She is cut into eight pieces. She is killed a second time, and the bones re-unite after eight showers of rain. She submerges a village with eight waves. This last connects her story with that of the hero Rapuanate, who went to Ulawa (newly fished up from the sea with a hook by the hero Mauua), and bought eight waves, with which he submerged Teonimanu (Hanua asi). We do not give the whole of the story. When old Walakalia had brought the serpent back from its wanderings in Florida, he remarked, "We have now completed the trunk of the tale; here it divides into two long branches. We will follow one and when it is finished we can return to the other." Which he did. So, too, we have condensed the story of Rapuanate, which, say the natives, "takes one whole day to tell, beginning at 
sunrise and talking steadily till sunset." The following is "the trunk of the tale" of the figona serpent Walutahanga.

Her mother was a woman named Huapiaoru and her father's name was Porokalihidani. Her father and mother lived at a place called Sihora near Langalanga on the west coast of Mwala. One day Huapiaoru conceived, and in due time her daughter was born, but it was a snake, and her mother was startled and afraid as she had only expected an ordinary child. There was no one else present, however, and the snake said "Don't be afraid of me, mother, but take care of me and I shall do you nothing but good." So her mother took her and hid her under a pile of firewood by the wall. When the husband came home he said, "Well, wife, where is the child?" "It is dead," she said. After a time she conceived again and bore a daughter. All this time her husband knew nothing about the snake which lay hid in the house. When he and his wife went to work in their garden she made him go first and she would remain and call out her snake daughter to take care of her little girl, the snake's sister. The snake coiled round her and made a cradle for her. Then the woman followed her husband to the garden and when he asked her, "What have you done, wife, with our little daughter?" she would reply, "I left her with her grandmother." So when they went home again after their day's work she would go first, and when she got near the door she would rap loudly on the flat roots of a large tree, and the snake daughter would slip away and hide. But after a time her husband noticed that she always went out last and came home first, and he felt sure she was concealing something, so when he went off down the path one day he did not go far, but slipped back through the bush and hid near the door. Presently, his wife came out, shut the door, and went off to the garden. The husband stood listening, and presently in the house he heard the sound of singing, and it was the snake singing to her sister the following: sleeping song:-

Ro ruru ro, ia ruro, osa ngarangara,

No kaa too a aeku ni ura hai inio,

No kaa too nimanimaku huni akololoio;

Ro ruru ro, ia ruro.

That is to say:-

Ro ruru ro, ia ruro, don't cry,

I have no feet to stand with you,

I have no arms to embrace you,

Ro ruru ro, ia ruro.

The baby was just sinking into a soft sleep when the man came in and saw the coils of a snake round his daughter. "You are making my child cry," he called out, and chopped up the snake into eight pieces with his axe, and threw the pieces outside. Presently, Huapiaoru came home to see what had become of her

1 Really her sister. 
husband, and there before the doorway lay scattered the eight pieces of her snake daughter. Her mother sat down and began to cry, but the severed head said to her "Don't cry, mother, I must go away, for my father doesn't like me, and wishes to kill me; go and get me eight leaves of giant caladium" (a sacred leaf). Her mother went for the caladium leaves and the snake called to the sky that rain should rain upon the earth, and a great rain rained for eight days. On the eighth day, the severed pieces of the snake reunited, and she lay by the stream which the rain had brought down, ready to depart on her travels, but as yet she had no canoe.

After a time a banyan came floating down upon the waters, and Walutahanga climbed on to it, but it was too short. "This is not my canoe," said she. Presently another tree, an atare, came floating by, and the snake climbed upon it, but it was too short. "This is not my canoe," said she. At last a third tree came down, a mute, and this was the right length. "This is my canoe," said she, and she floated away down the river and out to sea. First she went to Marapa, the ghost land (Marau Sound), and landed at Qaeralo. But when she had landed she looked back and saw her home. "I am still in sight of home," said she, "I must go farther." Where she landed there is a pirupiru, a sacred grove, to mark the spot. She went off again on the mute and this time she came to Boromoli close to Siota in Florida. Since that time there has been a pirupiru there, where she landed at Lumu. But she looked across the sea and saw her home. "I am still in sight of home," said she, "I must travel farther." So she set off again in her canoe and came to the farther side of Florida, where now there is a great cave up which a canoe may be paddled, but there was no cave there then. Here she encountered an octopus; "Where are you going, evil long body and crooked tooth?" said the octopus; "don't come near my canoe-house." She made no answer. "If you come any nearer," said the octopus, "I shall kill you." "But I don't want to harm you or drive you away," said the snake. "I am a wanderer. I have no home." The octopus called out wicked words to her, and she became angry and rushed upon him. He backed suddenly in fear and broke a large rock behind him. She rushed at him again and he backed away from her, right into the cliff, breaking a passage into the solid rock, and that is why there is a cave there now. The snake followed him, till at last he squeezed into a cranny where she could not see him, and she passed him, and went on, up into the island. She went into the bush and found a cave in which to live, and here she stayed. No one knew of her arrival, till one day a party went fishing on the reef and one of them felt hungry. The cave where Walutahanga was living was in his garden. He said to the others "Wait here for me and I will go and get some bananas." Now the bananas grew just at the mouth of the cave. So he went, and one bunch was ripe, just at the cave's mouth, but as he put out his hand to pluck it, the snake seized him, pulled him into the cave and devoured him. His companions waited some time, but as he did not return they supposed he had gone back to the village, so another of them went to the garden to get the bananas, and he too was devoured in the same manner, and 
so was the third. Then the people said to one another, "Something must be the matter. Let two go together." So two of them went; one stood a little way off and the other went to pluck the bananas. Out came the snake, seized him and pulled him into the cave. His friend who saw all that happened returned to the others and all of them hurried up to the village, where they and all the people armed themselves and set out for the cave, to kill the intruder. But though they went out valiantly very few came home again, for the snake pulled them down one by one and devoured them in the cave. So they began to look about for a charm, and one of them remembered two famous man-eating dogs living at Langalanga in Mwala. Two of them took a canoe and paddled over to Langalanga. The owner of the dogs lived up in the bush, so they went to him, and there he sat at the door of his house with his two famous dogs, who barked with joy at the sight of men to eat, but were restrained by their owner. "What do you want?" said he. "We have come here," they replied, "to hire these dogs to destroy a terrible man-eating snake which has come to live in our country." So he said, "Very well, you shall have the dogs, but go first into the garden to get some taro, and I will send the dogs to show you the way, and to-morrow you can go home." "All very fine," said they, " but the dogs will eat us." “No," said he, "I will tell them not to." So the dogs ran before and they followed them and dug taro in the garden and came back again and slept there one night. Next day they set off for home again, taking the two dogs, who had been told what was wanted of them, and were howling with delight at the thought of fighting the snake. When they got near the shore, the dogs smelt the snake and nothing could hold them back. They jumped out of the canoe into the sea, swam ashore, and rushed off into the bush, straight to the cave. The younger said to the elder, "Do you go to the mouth of the cave and draw the snake out with your barking, and I will climb up above and jump down upon it when it comes out to seize you."

So they did. And when the snake heard the dog barking she came out, one fathom of her. But the dog called to his brother above, "Not yet, let her come out farther." So the snake came out farther, and when she had come out three fathoms, the dog above leapt down on her and bit her neck, and the other dog rushed in and helped, and the people who were all standing round with spears and axes rushed in also, and Walutahanga was cut to pieces, and stabbed in a hundred places till she was dead, eight pieces lying on the ground.

Then they divided the portions and gave one to a woman and child, and this was the head of the snake. Each man made a fire, and cooked his portion and ate it, and the woman and child made a fire to cook the head. But the smoke blew into their faces, and they began to sniff, and the tears stood in their eyes with the smoke. "Ah," said the head to the woman, "you two pity me, you two alone out of all these people; you shall not regret it; you may cook me, but don't eat me." So the woman and child cooked the head but did not eat it. Then the rest said, "Each of us must bring the bones of the portion he has eaten, and when all have been collected on a day we will take them far out to sea, and throw them 
into the water." So they did, but the head bones were absent. They asked the woman and child where they were, and they replied that they had cooked the head but had not eaten it; so the people took it from them and ate it. Then they chose a day, and all launched their canoes and carried the bones far out to sea and threw them overboard into the sea, where they sank to the bottom out of sight, and all the people cheered lustily. But they might not have done so had they seen the bones re-uniting bone to bone at the bottom of the sea. Then came eight showers of rain, and at the eighth the snake was whole again, and stretched herself at the bottom of the sea with a noise like thunder. "What is that strange noise?" said the people, and paddled home as fast as they could go. But still faster went the snake under the water, and as she went she made eight great waves, and the eighth overturned their canoes and drowned the people in them, and rolled over their village, destroying everything in it. Then Walutahanga bethought her of the woman and child, and went to seek them. She found thern in the branches of a banyan, safe and sound. "Come down, friends," said she, and made to grow for them coconuts, yams and taro, and made a stream to flow, and gave them pigs. "Now," said she, "I have prepared all this for you, but I myself must go away, for I see clearly that the people of this land do not want me, and only wish to kill me."

So she set off again and came back to Langalanga, but not to Sihora, her home. On that day a man was fishing with a net, and saw her coming in from the sea, a snake of terrible size. "Don't be afraid of me," said Walutahanga; "I, like you, am born of woman, receive me kindly and all will be well." "But," said the man, "I am afraid of you, long evil body and crooked tooth." "If you will receive me," said the snake, "your garden shall be fruitful, and you shall be successful in war." "But," objected the man, "my canoe is much too small to hold you." "Let me but rest my head in it," replied the snake, "and paddle ashore with me." So he did. When they got ashore people began to come together, and the snake said to the man, "Go and build me a house to dwell in." "How am I to do that?" said he; "I shall take years to make one big enough." However, she told him that all he had to do was to get eight leaves of cane and eight leaves of giant caladium, and with these he made her a house. So the snake lived there and helped him in all his undertakings, and has been worshipped ever since by the people.

Walakalia, who told the tale, is one of her worshippers.

\section{Prayers and Charms.}

Before describing the ataro it will be well to give some account of the way in which they and the figonc were approached, and the spots where this took place.

The word used for prayer in translations of the Bible is ritungai. This word appears again in Ulawa and Mwala as lihungai, and in Florida as 
liulivuti, the root livu or lihu being the same. According to Dr. Codrington lihungai was used when ataro ghosts were applied to for help in battle, in sickness and for good crops. "Lihungai, the word they use, conveys rather the notion of charm than of prayer. The formula is handed down from father to son, or is taught for a consideration." This, however, is feiaru or feirunga, not lihungai. Lihungai can never have been so important a word, as its original meaning is now unknown to many natives. Another expression for lihungai is ha' a oheohe, which seems to mean "to fence off," while lihungai means rather "to separate." Both words were used of setting apart a man or woman from evil influences. Thus, if a man were wounded in battle by a spear, he would lie up in his house and only one man would tend him: no one else must go near him. Thus they would lihungai (or rather rihungai) inia, fence off on his account. So if a woman had given birth to a child, she was kept apart, no one, especially an adulteress, must approach her; the people rihungai inia, fence off on her account. It will be seen that rihungai is a very poor word for prayer. It has for some years been discarded, though it still remains in the translations.

Fagarafe is the word now used. Rafe means weary, and fagarafe to make weary, to importunate. In the account of the Agunua rites, a fagarafe has been given, asking Agunua to bless and protect the people during the coming year. Anyone might fagarafe, and any words might be used. Thus a man going fishing would go first near some rock by the stream and fagarafe to the figona of the rock for a good day's sport, or a man hunting pigs or opossums in the bush would stand near a rock, the abode of some figona, and say a fagarafe for good luck. There was, as a rule, no blowing on lime or leaves, as in a feirunga, and no special words handed down as in the feirunga. Fagarafe were made both to figona and ataro, and accompanied sacrifices. When, for example, a sacrifice of a pig was made to an ataro, the sacrificer would say, "This is your pig, given on account of my sickness for your eating, that I may recover my strength." But no special words were used, other words would do as well. And in the account of the sacrifice to the ataro Harumae, to be presently given, there occurs a fagarafe, "Harumae, chief in war, we sacrifice to you this pig, that you may help us to smite that place; and whatsoever we shall carry away shall be your property, and we also will be yours." But another form might equally well be used. Fagarafe means, then, a request to a spirit or ghost for help, and is in no sense a charm. Feirunga, or feiaru, or heiaru, is the other word in common use, and this is a charm. It must consist of certain words handed down from father to son, or from some man to his friend, and it is evident that these charms have been handed down for some considerable time, since they now contain archaic words no longer used in San Cristoval, though, perhaps, found elsewhere. For example, the word now used for lightning is some form of fireia, but in the charms parapara is used. In Mota in the Banks Islands manu varavara is an expression for lightning. Besides consisting of particular words a feirunga is almost always accompanied by particular acts, of which the chief is blowing upon something to impart mena, or power, to it. The techuical 
term for blowing upon the object is memena. Mena is probably a form of the widespread mana, and also occurs in another form in San Cristoval as manawa, the breath, or to breathe; mana or mena perhaps means originally the breath, and power is a secondary meaning, owing to the fact that it is the breathing upon an object which imparts power. While a feirunga is generally addressed to an ataro or figona, it may also come to mean a mere charm or omen. Thus there is a story of a famous ogre named Watarokaoka, who set out one day to look for food, and coming to the bank of a fast-running stream, saw a woman planting taro on the other side. He wished to eat her, but the stream was too deep and swift, so he pronounced a feirunga:-
Turita ahe su i tara
Wai tarau wau, wai gara.
(Translation.) Sink and flow back from the path,
I shall cross over and eat her.

But the woman, without turning her head, immediately pronounced a counter spell-

Rangi rangi mai ma nai Hau

(Translation.) Rain hither from the face of Hau.

And the stream still flowed as fiercely as ever, so that he could not cross.

A party going to war, feirunga first (feiaru or mawaru it is called at Marogu, where this was obtained). Each takes a dracaena leaf and says a feirunga, breathing upon the leaf, as follows :-

Siri ngatangata ura mara waraefu fata

Siri ngatangata ura mara waraefu kaura.

(Translation.) Dracaena firm stand, like the plume of the eagle

Dracaena firm stand, like the plume of the frigate bird.

Then he folds up the leaf, partly bites it through, unfolds it, and holds it up, straightening it out. He then lets go the top. If the leaf stands up straight, he will go and fight, if it falls over he will refuse to go. Probably this was addressed to an ataro. If he decides to go to war, he will then sacrifice and pray to an ataro ramo, an ataro of war, and then say a feirunga to it, so that the spears of the enemy may miss him. He takes lime, breathes upon it, smears a streak under his right eye, and pronounces the following words :-

Bubuni maana, mwani rurukape

Ta gugua oo, mai tatare

Ma bubuni, maana, mwani kekewa.

Ta gugua oo, mai akere.

(Translation.) Paint his face, all wagtails,

The spear aimed at me will miss;

Paint his face, all fantails,

The spear aimed at me will glance off. 
If a man has fever or a cough he goes to a stream, takes a dracaena leaf, breathes on lime and puts it in the leaf, stands in the water, and says the following words to a figona:-

Tatare au me ne su na ringa

Gu tatare au, susu kokoro au, me ne su na ringa

Gu kokoro na ringa, gu kokoro, gu tatare.

He then sprinkles the lime over his body.

We have a very long feirunga for rain, addressed to a figona, of which part may be given as an example of such charms. The man takes a dracaena leaf, breathes upon it, and holds it out towards the quarter of the sky from which he expects the rain, saying as follows (the language-Kufe-is that of Rafurafu) :-

Siriaku ni tangitangi rafa

Tangitangi raga fita faitanga

Siriaku ni paraparaga

Ngungurufi matawa rafa

Ngungurufi matawa riki

Furuia ta mai wai ta maramara

Totoragaraga ta mai rungana i wai ta maramara

Tora pokea gana fau kangurafa

Regea ta mai gana bwaoro rafa

Totorea tanga na matawa rafa

Furu marumaru tanga na pakewa rafa

Siri tapurara, ta nga, ni tangitangi rafa

Torotoro fagi piringe

Toro ragea ta gana pena fata rafa

Totora mamaopasia tamai wai rafa

Totora tanga napena mara rafa, etc.

(Translation.) My dracaena, let the great storm come,

A great storm, surf rushing both ways.

My dracaena, let the lightning flash,

Let the thunder sound on the far horizon,

Let the thunder sound on the near horizon,

Lightning speed hither, waters of Maramara,

Strike hard the source of the waters of Maramara :

Strike and tear out where the great rocks go deep,

Sweep down thence the great banyan,

Drag it to the far horizon,

Let it overshadow darkly the great sharks.

O red dracaena leaf, what is that? a great storm,

Roaring and pressing down; 
Roaring and dragging out the trunk of the great Fata, Carrying down the landslip from the great river, Carrying its trunk to Great Mara.

These are only the opening words of the feirunga which is a long and very fine description of a great storm on the coast.

There are feirunga to be said on all occasions. For example, a man wishes to drink in a pool where a figona or ataro may be present. He first takes a stone, breathes on it, says the following charm and throws it into the water:-

Fora, wai kakai robo, fora, ma wai kono

Fora, wai kakai asi, fora, ma wai ta wai.

After he has caught a fish and baked it on the embers of the fire, he says :-

Au ngaungau mamaru na ari kapukapu

Ataro i siofi au

Au ngaungau mamaru na ari wekoweko

Ataro i siofi au

Nga ni moamoaragi fitofito

Nga ni moamoaragi gapu

The following feirunga would seem to put the user of it under the protection of figona, lest any ataro should harm him :-

Au ngaungau i bwauna unu

Adaro si abwai ngou

Au ngaungau i bwauna mwa

Adaro si abwai wana.

(Transtation.) I am eating the head of the snake;

Adaro over yonder, let him not speak.

I am eating the head of the snake;

$A d a r o$ over yonder, let him not see.

Naturally there are a great many charms connected with the management of a garden. There is a charm used when the place is chosen, another when it is marked out, another when some of the earth is cast hither and thither, another when the yams are planted, another at weeding, another when giving the yam a pull to make it grow, another when mourning over a garden which is not successful, another at training the yam up the stake, another at tying up the shoot, and so on. We give a selection of these from Tawatana in the part of San Cristoval called Arosi. This is the language of Bishop Patteson's vocabulary used by von der Gabelentz.

In choosing a spot for a garden a Tawatana man goes into the bush with his axe, breathes upon the axe, and cuts through a sapling or creeper, calling on an ataro known to him, or on the hiona of the place, to observe whether it is a 
suitable place for his garden. If the cut is a clean one the spot chosen is a good one, but if a bit of the sapling is left sticking up, someone will die. If several bits are sticking up, another spot is sought. If the spot chosen proves to be a good one, four stones are then put at the four corners, and these stones remain after they have been charmed, to keep off anyone who may come to spoil the garden. The following is the first heiaru used for the stones :-

$\mathrm{Au}$ didiusi mou mana mata raha oi boi ta e mata raha, nagu ano ta tabara, oi boi mata gegena mou agaraa, oi omeome ta e mata raha, oi ome tarihana sae nai haataia i mou agaraa, e sae e boi haataia i mou agara oi ngahuia ta e mata raha, oi taba nai waera ana, oi taba magamagaa, oi boi taba abaabana oi taba haamaranga, ma e sae na e taha moi haraana, ma oi ua, oi nigaa ta mai taro tahataha, moi itai tarai agaraa, ma e sae na e babasia e dora iagaraa ma oi ngahuia ta, oi ngahuia ma oi gasi ngangahuia mou agaraa, maragu unu garaa sae garaa aia toora haa ni wate uru bwarasigaraa ami oi waa maegu mae nai ruma iana, maraigu unua do e adaro na ngahuia nai ruma iana.

(Translation.) I make a spell for the garden and for you, great Mata. Come, great Mata, and my land will yield plenteously, come and sit by the side of the garden of us two. Look after it well, great Mata. Notice carefully anyone who spoils our garden. Should anyone come to spoil our garden, slay him, great Mata. Strike at his forehead, strike and crush it. Strike his shoulders and dislocate them. Should a man come without evil intent, let him go free. Should a man come to spoil our garden, kill him, etc.

This charm is used for the first and third stones. Another to the "Little Mata" is used for the second and fourth stones, as follows :-

Au didiusi mou mana mata rii, au didiusia nagua ano ni uhi ano mamauri, oi boi ta e mata rii oi boi mato nai nagua didiusi, oi omesuria mou agu ni, e sae nai e maataia ni mou agu ni, oi reia e mata rii, oi boi taba i huna nai bwauna isi, oi taba romo isi, oi boi taba nai bwauna ababana isi, oi taba haa mararanga isi, oi ngangahuia, o gasi ngahu haamaesia isi, sae agaraa toora haa ni wate uru bwarasi garaa isi, oi waia ma oi gu ngahu haamaesia nai ruma i ana isi, maraigu unua do e adaro na ngahuia isi, au gege usi mou mana mata rii, au didiusi mou mana mata raha.

(Translation.) I make a spell for the garden and for you, little Mata; I make a spell for the ground that my yams may live. Come, little Mata, come into my spell. Look after this my garden. Should anyone come to spoil my garden, thou wilt see him, little Mata. Come and strike the back of his head. Strike him on the point of his shoulder. Put it out of joint. Kill him, but do not strike him dead there (in the garden). Let our friends who have money give it for us. Do thou take him and strike him dead in his house away from here and they will say that a ghost has killed him there. I make a charm for the garden and for Little Mata; I make a charm for the garden and for Great Mata. 
After this a dracaena leaf is taken, and the action of sweeping the garden with this is performed from end to end, after which the leaf is thrown away in the bush. The following charm is used:-

Au dedehe mou nae wai na rafa, au dehe gasingai ie ni ano ta taa, an dehe gasingai ie ni ano haasiriani, au dehe gasingai ie ni ano susuhari ana, au dehe diohainia nai urungana $i$ wai na raha, au dehe nugaa nagua ano ta tabara, ano na gorogoro ni hingana, mai boi ai rafa tagua uhi ana, au dehedehe mou urungana $i$ wai na rii, au dehe gasingai ie ni ana haihasiri, au dehe gasingai ie ni ano ta taa na isi, au dehe diohainia nai urungana $i$ wai na rii, au dehe nugaa nagua ano mamauri, ni ano na gorogoro ni uhi, au dehe mou urungana i wai na rii, au dehe mou nai wa na raha.

(Translation.) I fan the garden towards the great water. I fan and clear away the poor soil, I fan and clear away the clayey soil. I fan and clear away the soil in which are scorpions. I fan them away into the source of the great water. I fan here soil that will bring forth plenteously, good soil for the seed yams, that on its coming my yams may be big. I fan the garden towards the source of the little water. I fan away all the bad earth, I fan it away to the source of the little water. I fan hither living soil, good soil for the yams. I fan the garden to the source of the little water, I fan the garden to the great water.

A yam is next planted in the garden and a charm said while breathing on the yam :-

Au hasia nagua na hua $\mathrm{i}$ uhi totora raha, au hasia nai duina i mou agaraa au hasi ia nai bae uru nai mou agaraa, nagua huhua i uhi totora raha, au hasia mae boi tabara nai rarona i mou agaraa, wai hasio o gasi roborobo bwaranga, wai hasio oi tari hane nai ranga $i$ hata, oi riosia ahoi ni mou agaraa moi reia ni waana ni uhi agaraa, oi omesia ni haibu usuri ana ni waana $\mathrm{i}$ uhi agaraa, oi reia nai haidaa ohi ana ni uhi nai rarona $i$ baraa, oi reia nai hai regesi ani ni uhi nai mou agaraa, rai taha naganaga inia i uhi agaraa, marai mwaosia suri oma, maraigu waa taringa ada nai oma ma waigu rahia ta ana toba raha, ai gu goni ni mwani wagi raha $\mathrm{i}$ oma, raigu suuhia ni ano nai uhi agaraa, agu ari wou gere hasi oou taa agu ura nai maa nai taoha raha, ma gu awara haida agu aoni moui haataa ana ma idingare raha ma moi oraora bewabewa, makasa suruia gasia mano i tari waa, a onaa magewa i raboo raha na waro moi abu i haa, a gasi magama, moi ha moia ta ma idingare raha.

(Translation.) I plant my big well-growing yam. I plant it in the corner of our garden. I plant it at the big stake in our garden. I plant my big well-growing yam, and it will bear plenteously in our garden. I plant you, but do not run to leaf only. I plant you, and do you climb up to the branch of the hata and hang down again into our garden. Thus will you see the beginning of our yam. You will see the top of our yam beginning to rise up. You will see it lifting itself above the ground in our garden. You will see the yam springing high up in our garden. The chief men will come along the path, they will come and covet our yam. And all the village will be astonished at it. And they will take them into 
the village, and I will take down a big food bowl. Then will the wives of the chiefs gather together in the village. And they will peel one of our yams. Then will a poor maiden go and stand at the door of the big men's-house and call out with langhter: Cut off a large piece and cut it up in pieces, then you can lift it on one side on to the split coconut-leaf, do not take rattan to lift it whole, lest it should fall and break like a big food bowl. Take only a large piece.

This long charm is pronounced by the man alone in the garden; others come afterwards to help him to plant. It is said over four yams, one of which is planted at each of the four corners of the garden.

Later, when the yams begin to sprout, the shoots are twined round stakes driven into the ground beside each mound. The following charm is used when staking the yams. The man takes his axe, breathes upon it, and cuts his stakes, four in number. If the man to whom the garden belongs does not know a charm, he seeks a man who does, and sacrifices to this man's adaro. The man who has dealings with the adaro eats the sacrifice, and then says the charm for his friend's garden :-

Au taunia nagua ira mahera raha, au taba $i$ waana to marawa, au suruia nagua waroi mananga, au hioa nai waana gagamwa hata, oi tari hane nai raana gagamwa hata, oi tari hane ma o gasi roborobo bwaranga, gasi robo mara waroi dahihi, au horo raha, oi robo hai ano ni uhi agaraa oi robo raesia tamua baeura nai mou agaraa ra tae ngona i mwara raha, naohia mai ni robona $i$ uhi agaraa, ra unua do ona hungana i asi rii raha, au taunia nagua ira mahera rii, au taba nai waana to mauri, au suruia nagua waro $i$ uhi, au hiriia nai waana gagamwa rigi, oi tari hane nai raana gagamwa rigi, oi tari hane moo gasi roborobo pwarii, oi robo mara uhi, o gasi robo mara waro $\mathrm{i}$ dahihi, o robo pwarii, ra tae ngona i mwara rii, ra naohia mai nagua robo i uhi, ra unua do ona hungani i asi rii, au suruia nagua waro i uhi, au suruia nagua waro i uhi marawa, nagua uhi tototo aba.

(Translation.) I take up my big broad stone axe. I chop the butt of a green to tree. I lift up the vine of my mananga yam. I twine it round the stake as big as a hata tree. Do thou climb up to the branches of the hata stake. Climb up, but do not make much leaf, without tuber; do not spread like the creeping vine of the dahihi, spread and make the tuber of our yam. Spread and break down the growing stake in our garden. They will embark at the point of Great Mwara (Malaita), they will point hither at the spreading vines of our yams. - They say that it is like the mountain Asi rii raha. I take up my small broad stone axe. I chop the butt of a living to tree. I lift up the vine of my yam. I twine it round the big rigi stake. Do thou climb up to the branches of the rigi stake. Climb up, but do not deceive with thy spreading vines. Spread as should a yam, not deceitfully like the creeping vine of the dahihi. They will embark at the point of Little Mwara, they point at the spreading vines of my yam, they say that it is like the mountain Asi rii. I lift up the vine of my yam. I lift up the green vine of my yam. 
When the time for weeding arrives, another charm is said, breathing on the first weed as one pulls it out:-

Au amuamu tahamwa, au amuamu taha i tara na hura agu boi ranga, agu boi hane taha, ma na uhi a bwani raha, au amuamu taha i toohoro na hura agu mato mana mou a bwani robo, agu ari mato mana uhi a bwani mato, au amuamu taha $i$ toohoro, au amuamu taha i tara.

(Translation.) I weed for the first time. I weed up to the paih. The new moon appears and gets high in the sky, and the yams are already big. I weed up to the boundary logs. The moon sinks down, and the garden is already covered with vines, it sinks down and disappears, and the yam already has sunk down in the ground. I weed up to the boundary logs, I weed up to the path.

To make the ground fruitful, four handfuls of earth are taken up and cast forth over the ground, the man who does so first breathing on the earth. The following is the charm:-

Au rarasa hairiu, a rerei naho nai Bwararii na mou agua abwai dorai riu, au rarasa hai tanga, a rerei i naho nai Mwara, mou agua abwai dora i riu taha.

(Translation.) I sprinkle in all directions, like the breaking surf at Bwararii, that there be no space left in my garden. I sprinkle in all directions, like the breaking surf in Mwara, that there be no way through my garden.

To increase the size of the yam, some leaves or grass are held in the hand, and breathed upon. This handful of grass is then held over the top of the growing yam, while the following charm is pronounced:-

Au amuamu gare huhusu, nabwauna i uhi agua nai husu, nagaona nai susu, au amuamu gare rerege, na bwauna i uhi nai rege, nagaona nai tere, amuamu gare rerege, amuamu gare huhusu.

(Translation.) I weed the springing child, may the top of my yam spring up, may its base push downwards. I weed the jumping child. May the top of my yam jump up, may its base go down. Weed the jumping child, weed the springing child.

If the yam is backward, the man breathes upon his hands, gives the yam a pull, calls aloud, and says the following charm :-

Au taho uhi kewakewa, uhi agua ai husu mara baewa, au taho uhi kirokiro, uhi agua ai husu mara girio, au taho uhi kirokiro, au taho uhi kewakewa.

(Translation.) I pull the yam, jutting up, that my yam may spring up like a shark. I pull the yam from side to side that my yam may spring up like a porpoise. I pull the twisting yam, I pull the jutting yam.

When the yams fail to come up a charm is used, called a charm " ini angisia $i$ mou," that is, for lamenting over a garden. The man breathes three times on the 
soles of his feet, and walks through his garden over the bare places, where he wishes the yams to spring up, saying the following words :-

Basu na uhi, boi basu mauri, basu na hana, boi basu manawa, boi pwira manawa, boi pwira mauri.

(Translation.) Sprout at the side yam, come, sprout and live, sprout at the side prickly yam, come, sprout with vigour. Come, shoot up with vigour, come, shoot up and live.

If a vine falls from its stake, the man picks it up and puts it on another, where it shall cling like a snake or bat. The following words are used:-

Hihiri na roi, totoki na roge, kakaka na roge, hihiri na roi, kakaka na roi, totoki na roge.

(Translation.) Twine yellow snake, hang flying fox, stretch out flying fox, twine yellow snake, stretch out yellow snake, hang flying fox.

When he ties up the vine, he says :-

Au hoohoo rau, au hoo buria ni au, au hoohoo uru au hoo buria mumu.

(Translation.) I tie up the shoot, I tie it close to the bamboo, I tie up the hear of shoots, I tie it close to the mumu.

While saying this, he breathes on dracaena leaves and then tears them to pieces.

It will be noticed that in these charms, of which there are very many, we have the germs at least of true poetry. Many of them in fact are poems, rich in simile, with a rude rhythm, and showing considerable command of language. The set of garden charms from Tawatana given above, contain several words, such as mara, "like," which are not ordinarily used in that part of San Cristoval (where " like " is ona), but which are the common words in use in other parts. It is worthy of note, that there is a heiaru used in a bush village inland from Wango, in which the name of Jesus is used. The name has not been inserted in very recent times, though no doubt since the introduction of Christianity along the coast.

\section{Ataro.}

Ataro or adaro is the name given by the natives of San Cristoval to beings, other than figona, whom they worship. In some parts (for example ten miles, inland from Pamua) the soul is called ataro mauri, i.e., living ataro, while still in the body, and ataro merely, after death. Elsewhere, as at Wango, there is a separate word for soul, aunga; when the aunga leaves the body it becomes an ataro. One great class of ataro consists therefore of ghosts, and it is these chiefly that are worshipped. There is, however, a second class of ataro, perhaps not as numerous as the former - spirits of the sea, woods, and shore, and others found in the rainbow and the waterspout. These are not ghosts.

The same word is found in the form akalo at Ulawa and in Mala, and the same distinction holds. Some akalo are ghosts and some are spirits. Farther west the 
Florida word tidalo is thought to be another form of ataro, but apparently tidalo never means anything but a ghost. ${ }^{1}$ To the south-east the word is believed to reappear in the Banks, where tataro is used for prayer, but is properly the name for beings addressed in prayer, each prayer beginning with this name. The word may have an even wider extension if the Samoan talo a prayer, the Tahitian tarotaro a short prayer to the gods, the Hawaian kalokalo prayer, and Gilbert Islands tataro, are really the same word, the use in the Banks Islands connecting the two meanings of ghost or spirit and prayer.

Natives of San Cristoval firmly believe in the continued existence of the soul after death. Death is merely a migration. The soul may pass into an animal, or may be born again in a descendant, or may merely exist without any incarnation. A ghost may also possess a living man, or as many as one hundred ghosts may do so. A soul may also be held captive in some sacred place, the outward sign being the decay of the body. The soul goes out in dreams and in unconsciousness. Death affects the body but not the soul. Mae, death, is the going out of the soul from the body, so that a person who is unconscious is said to be mae, dead. A person may be very ill, there may be obviously no hope of his recovery, but he is not mae till he becomes unconscious.

All souls are believed to go to Rotomana, which is variously situated, and live there a life more or less like their former earthly life. There is an ataro at the entrance to Rotomana, a spirit not a ghost, who only admits ghosts who have their ears and nose perforated and the proper marks under the right eye. There is also a spirit ruler of Rotomana. The Three Sisters are Rotomana to the people of a large part of San Cristoval. Islands in Marau Sound are the Rotomana of others. Living men may go to Rotomana and see ghosts and ghostly footmarks and hear strange noises. What seems at first sight illogical is the fact that along with this belief in Rotomana, there is a firm belief in the continued presence in the village or near it of the souls of the dead. In this double belief there is perhaps the evidence of the meeting of two cultures and two beliefs as to what happens after death. After death a great many ghosts become incarnate in animals. It may be wondered in what way natives determine the particular animal into which the ataro of a dead relative has entered. It depends partly on where the man is buried. It is a common practice to bury in the sea both chiefs and common people, and their ataro naturally become incarnate in fish, especially in sharks. But even if a man is buried on shore his ataro may enter a shark. After his death his skull and other relics may be put into a wooden figure of a shark, which is then securely sealed with canoe gum, and allowed to float in the sea. Watch is kept, and the first thing seen to approach it is the future incarnation of the ataro. Usually a shark, it may also be an octopus, a skate, a turtle, or a crocodile. But all ataro have not a. sea incarnation. When a man or woman grows old, natives watch to see whether any animal persistently associates itself with them. This is often a bird. The

1 The Melanesians, p. 127 : "Every tidalo was once a man."

VOL. XLV. 
bird comes to the house and perches on the old man's shoulder. It must be a young bird. It is fed and treated respectfully as the future home of the man's soul. When he dies his soul is known to be in the bird. His children will not eat any bird of that sort. This taboo seems only to last for a generation. There is a man now living at Raumae whose father's ataro went into a hawk, tehe. This man cannot kill any hawks or eat them, though other people do so quite freely. Birds into which the ataro goes are the hawk, the afitaronga, another kind of hawk, the aususuwai, a kingfisher, and the vaifirufiru, a small black and white bird. Or again, the ataro may go into a stone or a tree. This is known by dreams after a man's death. If in the dream the ataro of the man is seen at a stone, or by a tree, that is known to be its incarnation. Thus there is an ataro in a topaga tree near Rafurafu. The man's children will not cut down this tree, or any other topaga tree. Sacrifices are made there to the ataro. Dr. Codrington mentions the case of a man at Ulawa whose soul entered the banana, so that bananas became taboo. A man will say, I cannot eat such and such a fish or bird, because it is my father or my mother. Such beliefs of connection with animals should be compared with the Banks Island belief in a tamaniu, but the association with the tamaniu begins at the time of birth, while in these San Cristoval examples it begins at the time of death. Obviously totems might originate in this manner. The natives have other opinions as to the origin of totems and clans among them; the Ataro clan, for example, is thought to have originated in the actual resurrection to life of a dead woman and her child, from whom the clan has sprung. But after all, these native stories to explain the clans are simply the theories of the native anthropological society as to the origin of totemism. They are exceedingly interesting, and some of them may be true. The following are native explanations of the origin of San Cristoval clans:-

The Kafiko or Owl clan began in this manner: A child was crying for her mother, but her mother did not come quickly, so the child ran off by herself into the bush. Her mother followed her, but the child climbed a tree to escape her. The mother-climbed after her, but the child climbed higher, crying as she climbed, and finally changed into an owl. She was the mother of the Owl clan, and their forbidden food is an owl.

A woman and her child died and were buried. One day the child rose from the grave and came into the village and played with the children till sunset. Then she went back to the grave. The other children wondered where she had gone, and next day the same thing happened. At sunset the strange child went back to her grave. The children began to talk to their elders, and these determined to set a watch. On the third day, as the child was about to descend into the grave, the watcher seized her. "Leave me alone," cries the child ; "I must go to my mother, she is waiting for me below." "You are not telling the truth," says the watcher ; "if your mother is indeed waiting for you below, call her up." The child did so, and the mother rose from the grave. The two then returned into the village, and the child became the mother of the clan called Ataro. 
In these cases wonders are related to account for the origin of the clan, transformation into an animal and resurrection from the dead. But other explanations are more prosaic. For example, the Uraua clan is said to be an offshoot of the Amwea. An Amwea woman, according to one account, was living at Pounamou in the interior. She was carried away in a freshet of the Wairafa River, but saved herself by clinging to the trunk of an uri. On this she was carried out to sea, and right across to Ulawa, forty miles away. After this involuntary visit, she returned, having married a man of Ulawa (called Uraua in this part of San Cristoval). Their daughter was the mother of the Uraua clan. In this case there is no food restriction, since the uri has no edible fruit. But a member of the clan may not cut down an uri, or carry any part of the tree. The name of the clan is not the uri, but Uraua, to commemorate the visit. But twenty miles along the coast, there is a different though similar story to account for the origin of the clan.

When the souls of the dead dwell in animals, the animals are endowed with human understanding, and may aid the living. In some cases a snake of this sort was sent to kill a man. It should be observed that this snake did not attempt to bite the victim, but merely went to the man's house and lay coiled in some corner. The man would fall sick and die. A man who buried treasure in the ground would send a familiar snake to guard it; the snake would lie coiled round the stone where the treasure was. Some, however, consider that these snakes were figona.

Undoubtedly the chief incarnation assumed by ataro was the body of a shark. All sharks are not sacred, but a great many are thought to be possessed by ghosts. At Ulawa there were two familiar sharks who were widely known and respected: Sautahimatawa (mentioned by Dr. Codrington) and Huaahu. Huaahu has been slain, but his rival is still said to exist. These ghost sharks did not harm their worshippers, but were often sent by them to kill men at a distance. Familiar sharks were sent from Ulawa to Ugi and San Cristoval, forty miles, to kill an enemy. The following account of the proceedings in such cases comes from Ulawa, but it applies equally well to San Cristoval. At the village where Huaahu was venerated, if it were decided to send a shark on such an errand Huaahu was called by the priest, and told to go for his servants. Presently he returned with the other ghost sharks who would then fall in, their noses in a straight line. The next thing was to select one of them for the job, and this ghost shark was given some of the earth on which the victim's spittle had fallen, or some of the earth from his footprints in the sand. The ghost shark named then went off accompanied by a ghost skate, his helper. They would come upon the man in his canoe. The skate struck the canoe with its tail and overturned it, and then the shark swallowed the man struggling in the water, or rather held him in its mouth, the man's legs sticking out, and set off for home. Arriving at the little bay, the shark threw the man out on the sand, not dead but weak and crying. He was then strangled and thrown back dead to be eaten.

The end of Huahu was a melancholy one. He was missed one day and diligent inquiries were made. The people heard that a very large shark had been 
killed in another village. They went to this village but nothing remained except the head. They inquired of the head, "Are you Huaahu?" and the head stood up to signify that it was. His people thereupon destroyed the gardens and canoes of the offending village.

One of the sharks known throughout these islands was partly human. The head was that of a shark, but part of the body and the legs were those of a man. Here, as sometimes in San Cristoval, the sacrificial stone was a large block of red jasper. The priest was said to be able to make this stone float in the water, and it certainly was very sacred, for if the man's shadow fell upon it, he would waste away. When the ghost shark Wairowo was killed by the people of Mwanihuki, the sacred tree in the pirupiru at Kaunasuku, where his home was, broke in two of its own accord.

Sometimes there were fights between these ghost creatures. Some while ago the people of Ulawa heard by means of a ghost shark that a famous and terrible ataro of Mwala was on its way to Ulawa. It was in the form of a monstrous snake. Word was quickly sent round Ulawa, and all the ghost sharks and ghost-octopuses assembled for the defence of home and children. At length the great snake ataro was seen coming across the sea from Mwala. The octopuses went out in the centre with sharks on each side of them. The octopuses then squirted out great volumes of ink, darkening the sea all round and half blinding the snake. The sharks attacked it on the flanks, biting it to pieces. The fight was long and fierce, but victory rested with the assembled ataro of Ulawa, and the tooth of the huge ghost-snake now adorns an Ulawa canoe-house.

\section{Sacrifices and Shrines.}

Sacrifices were made in San Cristoval to ghosts and to spirits, to figonx spirits and also to ataro spirits.

A sacrifice to a ghost is described by a native of San Cristoval. This ghost (Harumae) is still known along the north-east coast, but the account of the sacrifice of a pig to him seems to have been given by a Wango native. The sacrifice was made when the people were proposing to go to war. The men assemble. Then "the chief sacrificer goes and takes a pig, and if it be not a barrow pig they would not sacrifice it to that ghost; he would reject it and not eat of it. The pig is killed (it is strangled) not by the chief sacrificer but by those whom he chooses to assist, near the sacred place. Then they cut it up; they take great care of the blood lest it should fall upon the ground; they bring a bowl and set the pig in it, and when they cut it up the blood runs down into it. When the cutting up is finished, the chief sacrificer takes a bit of flesh from the pig and he takes a coconut shell and dips up some of the blood. Then he takes the blood and the bit of flesh and enters into the house (the shrine) and calls that ghost and says, 'Harumae! Chief in war! we sacrifice to you with this pig, that you may help us to smite that place; and whatsoever we shall carry away shall be your property, 
and we also will be yours.' Then he burns the bit of flesh in a fire upon a stone, and pours down the blood upon the fire. Then the fire blazes greatly upwards to the roof, and the house is full of the smell of pig, a sign that the ghost has heard. But when the sacrificer went in he did not go boldly, but with awe; and this is the sign of it; as he goes into the holy house, he puts away his bag and washes his hands thoroughly, to show that the ghost shall not reject him with disgust; just as when you go into the really Holy House you take off your hat from your head, a sign that you reverence the true Spirit."'1

The pig was afterwards eaten. Things sacrificed in the shrine (hare ni asi) are called raherahe, while those sacrificed in the grove (pirupiru) are called ura' $i$, at Wango; where the word for sacrifice is ho'asi, elsewhere fogasi or pogase. Besides a pig, there was sometimes human sacrifice, especially to figond spirits; but the commonest sacrifice is a pudding made of grated yam or of almonds; this also is burnt, and part of it consumed by the worshippers. Other things sacrificed are areca nut, a drinking coconut, and various kinds of native money, shell money, dog's tooth money or fish tooth money. Fish also are sacrificed, especially to spirits of the sea. The first flying fish caught with a new float, or in a new net, are sacrificed.

Besides the annual sacrifice to Agunua or other figona, at the harvest, and also to ataro at the same time, there are sacrifices on all special occasions, both public and private, as when the village goes to war or when a man plants his garden. The following account of sacrifices was written for us by Maekasia, a native of Fagani :-

"We used formerly to attend to sacrifices. They did not sacrifice only in the shrine (rima ni asi); on the contrary our fathers sacrificed everywhere-in the sea, at the grove, on rocks, and in the village. Sacrifices in the sea were made, first to the spirits of the open sea (Ataro ni matawa) and secondly to men who died and were buried in the sea. They sacrificed fish, and puddings when the yams were full grown, and almonds. The fish and puddings were sacrificed to spirits of the sea because spirits of the sea are in the habit of eating fish, and coming to the shore they ate puddings and found them sweet in their mouths, and so they came to have a great partiality for eating puddings with fish, and so they sacrificed puddings and fish to them (my friends! how these spirits can eat!). Yams and almonds were sacrificed to men who died and were buried in the sea. For example, if one of you two, Drew or Fox, were to die, and he was buried in the sea at Tawapuna (a sacred place near Pamua), next year perhaps the survivor would be thinking of his friend who died, and he would get yam and almonds and take them to the place where the body was let down into the water, and he would throw them into the sea there with some such words as these: 'My friend (or my brother, or my uncle) this is my sacrifice to you, so that you may protect me this year when I dig my garden and look kindly on the produce of the garden.'

"At the rock in the sea sacred to sharks they sacrificed to sharks and to men 
who died and were buried there. At the shrine in the village they sacrificed to sharks, spirits of the sea and the dead, and in the village also they sacrificed to the spirits of the land, and to snakes and to those who died and were buried anywhere in the ground or in caves. So a living man would sacrifice to his dead friends, hanging up yams, almonds (fresh nuts), strings of shell money, dog's tooth money, fish tooth money and bat's tooth money."

Yams and nuts are hung up in the garden and in the house. After a time some of these are burnt, but merely to hang them up is to sacrifice. A green drinking coconut is put in the sacred place and afterwards removed and drunk. Private sacrifices are made when there is sickness, or when a man goes on a journey, plants a garden, or goes fishing or hunting. In the case of war, those who worship special ghosts will sacrifice to them first, and afterwards join the rest in a common sacrifice to some famous ghost like Harumae. People going fishing or on a voyage sacrifice first to spirits of the sea (ataro matawa) and people going hunting to wood spirits (ataro hasimou), ghosts (ataro), and spirits (figona).

As Maekasia remarks, sacrifices are made in many places, in the shrine of the village, in the sacred grove, in the canoe-house, in the guest-house, at rocks in the sea or on the land, by pools, under trees, and in the people's own houses.

In each house relics of the dead are preserved, the skull, or jawbone, a tooth, or hair. These are placed in a coconut leaf basket, and hung up at the top of the main post of the house. Sacrifices are burnt below and the smoke and savour of the burnt sacrifices ascends and is pleasing to the ghost. These ghosts are probably lately deceased members of the household, a beloved wife or child.

The ordinary place of sacrifice is the village shrine called hare ni asi or ruma ${ }^{1}$ ni asi. This is a small house about six feet square or less, only entered by the priest. In this is probably a small platform on which are five or six skulls or other relics of great men, underneath which sacrifices are burnt; or a bamboo may be stuck into the ground with the upper end split so as to form a conical basket in which the relics are placed. Here, too, are probably found some memorial stones of people of whom no relics have been preserved. The name given to this shrine is a curious one, rima, or ruma ni asi, i.e. sea-house, and in Bauro hare ni asi. At Bauro the ordinary word for house is rima, only the shrine is hare (the Florida vale house, the Polynesian fare or fale). Hahare, however, is a shed, and probably the usage is like that mentioned by the Rev. C. Bice in Oba, New Hebrides, where ima is an ordinary house and vale a shed for storing things in. But the expression ni asi, belonging to the sea, is a strange one, for the same name is given to it in the bush. An old native was asked why the bush people called their shrine the sea-house. He replied that in an ordinary village there were two houses where sacrifices were offered-the one called tawao, where spirits of the land and souls of those buried in the bush were worshipped and sacrificed to, and the other called hare ni asi, where the spirits of the sea and ghosts of those buried at sea received worship and sacri-

1 Also rima ni asi. 
fices. The bushmen, he said, worshipped the spirits of the sea as well as of the land. Possibly the invading people, who brought in the ataro cult, introduced also the name for the shrine, along with the worship of sea spirits (ataro matawa), sharks and ghosts.

The Tawao mentioned above is an ordinary native house, used as a guest house, and reserved for men only. There are no relics in it, and no priest connected with it, but it is usual to offer sacrifices on a pile of stones, at the foot of the main post; though at Wango the people say this was not done, and the tawao was there merely a guest house.

The Pirupiru is a name given apparently to two different places. The spot outside the village where one or several sacred trees grew is called Pirupiru. These trees are banked round with flat stones or enclosed in a stone fence. The usual tree is a small coconut with yellowish leaves called niu maho (the forbidden food of the Atawa clan in some places, though not in others ); other trees common are the pirupiru itself (Mota pirupiru), the sagirima and the taro. Besides these trees it is usual to find dracaenas, and crotons planted about them. Within the enclosure skulls are buried. On the stones sacrifices are offered both to figona and ataro. Anyone may come here at any time and sacrifice privately. This is the scene of the Agunua worship. At Raumae in the interior a similar spot is called not Pirupiru but Aritengari, i.e. the arite, a tree (Catappa terminalis) and the ngari or almond. This fact, and the name pirupiru, apparently from the tree pirupiru, seem to point to "sacred tree or grove" as the original meaning of Pirupiru. There is, however, a different place called pirupiru, the rock on the reef, where a shark comes, and where sharks are worshipped, and now at any rate most natives would think of shark worship when pirupiru is mentioned.

Besides these was the canoe-house (oh $\alpha$ in Wango) where relics were preserved often in wooden sharks, and sacrifices were offered, where young men and those engaged in bonito fishing lived secluded for months at a time.

In the bush are many rocks connected either with figona or ataro, where a man offered a sacrifice of pudding. The natives are confused as to whether ataro or figona haunted these places. There is one near Rafurafu which contains a cave. This is haunted at times by a small, dark, long-haired ataro, a spirit, not a ghost. His presence is recognized by the fact that when he is at home the rock sweats blood, which oozes out in great red drops. Whether the ataro is there or not a man passing will offer a sacrifice, probably a little betel nut.

Sacrifices are also offered in the houses built for sacred snakes, and in the sea as mentioned above.

Not anyone may sacrifice in the hare ni asi or at the shark pirupiru or to the snakes. Only the priest may do so and his office is hereditary, passing from father to son, either real or adopted or bought. The priest, of course, is a man of influence. He becomes possessed, and tells the people the wishes of the ghosts. He tries by omens in the hare $n i$ asi the will of the ghosts as to peace and war, heating dracaena strands and pulling them apart to see whether they break. 
Priesthood may be bought, at least in the shark worship. The following account of such a purchase as told by Maekasia of Fagani is interesting:-

"Perhaps at first there was only one pirupiru in the land and only one priest who had ghostly knowledge, the first of all priests of sharks. And he did his work regularly at the spot called Pirupiru, offering money, and dog's teeth, and the proper sacrifices. Other people had no power to do so, and there were no places where they could go. But then if a man wished to become the friend of a shark and worship him, such a man could not say, "I am a shark man," but he must send for the original shark man and he would make him a shark (by hunching up his right arm in imitation of a shark swimming, and touching him with it), and then he could perform the sacrifices with success; then the man who made him a shark by touching him would appoint him some place on the beach, where there was a rock where he might sacrifice to sharks. Thus, perhaps, many became the friends of sharks, and pirupiru were multiplied along the shore.

The following story is told of two persons called Karifia and Hagasuimae: "Karifia was a man of this place Fagani, Hagasuimae came from a place called Rara asi, in Bwauro. Karifia was a shark man with great ghostly power, very busy with his friends the sharks. Hagasuimae was quite a small boy, very beautiful to look upon. He was going through what we call maraufu, a period of seclusion for bonito fishing, and could not leave the canoe-house, where he fasted. His father and mother begged him to eat a little of the food which they had prepared for him, but he refused to eat anything, and sat quietly thinking to himself, 'I want to change into a shark, but how is it to be done?' His whole longing was to be with the sharks, and he cared nothing for food, but ate only coconuts: all other food he cast aside and lived on coconuts only. So he continued till he became ill with hunger, and as he lay ill on his mat, he said, 'Let someone go to Fagani and fetch Karifia to touch me for a shark, so that I may have ghostly power.' So Karifia went to Bwauro and touched Hagasuimae and said the proper words to turn him into a shark, and so the boy died and became a shark. It was Karifia

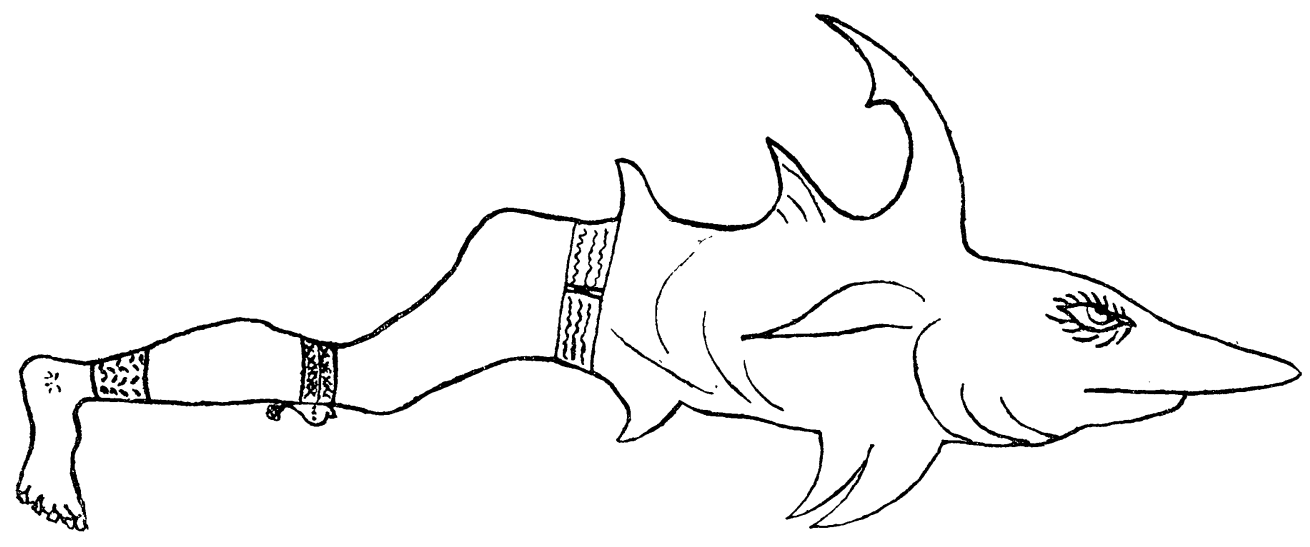

KAREIMANUA.

(Drawn by Maekasia, a native of Fagani, San Cristoval.) 
who laid his hand on him, so Karifia chose out a spot on the beach where he should be worshipped, a place we call a pirupiru, and the people there continued to worship Hagasuimae till they began to go to school."

Men like Karifia could send their souls into sharks, while their bodies remained in a trance. In this way they could hear news of absent people and learn of their doings. We give on p. 168 a drawing by Maekasia of the ghost shark Kareimanua, known by the same name in Mwala, Ulawa, and San Cristoval.

Possession by ataro is common. The priest who has charge of the village shrine becomes possessed in the ordinary course of business in order that he may know the will of the ghosts. He may become possessed in the hare ni asi or elsewhere. But other men too become possessed. A party on the war-path will wait while one of their number becomes possessed, to learn the issue of their expedition. A possessed man sees into the future, forewarns of coming events, gives news of the absent, decides who should lead the war party, whether they should allow a school in the village, and so on. A party in a canoe wishing to know whether it is wise to go on, wait while one of them becomes possessed. The canoe rocks violently from side to side when the ataro comes into the man. If it happens in a house, spears and clubs are first piled against the middle posts ; these rattle and are violently agitated when the ghosts arrive and possess the man. No one is standing near them. The natives remark that much deception is practised and that many cases of possession are fraudulent, but that in their opinion there is also real possession, which may be known partly by the real change of voice, and partly by the eyes, out of which a strange soul looks, not the soul of the man possessed. Possession is often brought on purposely, but is often involuntary. In the latter case the natives remark that other people of the same family are similarly affected. No doubt madness is considered to be a case of possession. While this article was being written, a case of so-called possession occurred among one of the boys at the school. The other boys came to us and told us that one of their number had become possessed. He first showed it by swallowing live coals from the fire. This desire to eat fire is a common sign. He then threw lumps of wood at the others when they tried to stop him and, breaking away from them, with a strength of which he was quite incapable at ordinary times, he rushed into the sea. They followed and succeeded in bringing him into the house. It was at this point we reached him. But the fit seemed to have passed, for although he appeared incapable of speech, perhaps from fright, he understood quite well what was said to him, and after his head had been cooled in cold water he went to sleep, quite happily, and was apparently all right next day. But the boys certainly considered it a case of possession by an ataro.

A case of possession was witnessed by one of us where. the symptoms were different. This was a Banks Islands boy, but San Cristoval boys who were present said that it differed in no respect from San Cristoval possession. The boy referred to, about 18 years old, complained of headache. He went to sleep, and after about three hours became "possessed." He was extraordinarily strong, about 
eight men, most of whom were powerful young fellows, endeavouring vainly to hold him. In the intervals of these violent paroxysms he spoke, certainly in a voice quite unlike his own. A compatriot, staring into his eyes, said to him, "What is your name?" "We are many," replied the possessed boy. "Is it so and so in you?" to which the possessed replied "Yes" or "No" till it was ascertained who were in him (various dead natives, some of whom were known to the writers). $\mathrm{He}$ was then asked for news of friends in other islands. Some inquiries he answered (his answers proved to be wrong in some cases: when the Southern Cross arrived, one native who was said to have fallen and hurt himself being quite well, and another, who was said to have gone on a journey, having stayed at home). Other inquiries he did not answer, saying, "None of us have been there lately." All this time he was exceedingly strong, and sometimes violent, and apparently insensible to pain. In about an hour he suddenly appeared to come to himself, staring wildly round, asking where he was and what we were round him for. After a long sleep of some 12 hours he appeared to be normal again.

An ataro which possesses a man is called a hane ataro-i.e. a leaping ghost, one which leaps upon a man.

A man may send his soul into other animals besides sharks. His body remains in a trance, while his soul passes for a time into a hawk (hada) or opossum (huto).

At Bore, in the bush, there is an ataro which is seen in the form of a dog. It appears as a different dog on different days. Some days it is a white dog, on uthers a black one; it may appear as a native dog or a foreign one.

An ataro lives in an opossum near Waitaa River. The opossum is called Huto Kapo; another name for it is Aranga Mae. If a man sees it, he will die.

\section{Tales of Ataro.-1. Ghosts.}

An ataro named Wowotagai, probably a ghost, lives at the source of the Aupare River, near Marogu, on the west coast. The bush people offer sacrifices to him. One night this ataro went to a village called Funauri. There he found a woman and child alone in a house. He tried to enter, but they barred the door against him. Wowotagai then climbed on to the roof, broke through the thatch, and killed both of them, and when the woman's husband returned he found his wife and child dead, the ataro eating them. The man rushed at him, but he climbed up through the broken thatch on to the roof. The man ran outside and waited there for him. Down jumped the ghost and the man chased him. The ataro ran right through the trunk of a big rigi tree, and the man went through after him. The ataro then ran along the path leading to Funariwo, came to the Aupare River, and dived in. The man followed. Both came out on the opposite bank, and the chase grew hotter than ever. The ataro came again to the Aupare and dived in, the man close behind. In the water the man seized the ataro, who cried out, "Don't kill me, or your wife and child will die for good and all." They clambered out on to the bank, the man holding the ataro and saying, "Now this very 
day you shall die." "Don't do me any harm," replied the ataro, " but go and look for a rata," a bamboo used for drawing water. "But," said the man, "if I go and look for a rata, that is the last I shall see of you." "No, indeed," replied the ataro, "I will wait here for you." So the man went to a clump of bamboos and chopped off one for a rata; and that stump may still be seen, it has not died and decayed. Then the man took the bamboo to the ataro, who charmed it, and vanished. The man drew water from the river in the charmed bamboo, and washed the corpses of his wife and child, who revived and lived. The bamboo he threw into the Aupare, and it floated away upon the stream. Sometimes you may hear the voice of Wowotagai, but no man has seen him again from that time.

A somewhat similar incident happened at Bore, on the same coast. An ataro found and killed a woman and child, and was proceeding to devour them, when the husband appeared. He chased the ataro, and succeeded in catching it by its long hair, just as it was going down a hole into the ground. He tied it by its hair to a tree and was proceeding to beat it, when it cried out, "Don't beat me, go and get some water in a bamboo." The man did so, the ataro charmed the water, sprinkled the corpses with it, and the dead woman and child came to life again. The man then released the ataro.

In the following two stories, told by natives of Bauro, the dead also come to life again. Waipuamaremare had in reality died and been living with the dead. Part of his story is not unlike that of Kamajaku, recorded by Dr. Codrington. ${ }^{1}$

Taraematava.-Taraematawa was going through maraufu seclusion in the canoe-house by the shore at the time of bonito fishing. They were secluded there for three months, ten of them, living apart from all women. One day they went fishing for waiau (bonito), and Taraematawa went off by himself. A sudden great storm came up on the sea; the canoe was swamped and Taraematawa was drowned, and his body washed up on a sandy shore far from his home, where it was soon buried from sight by the sand. There was nothing to show where he lay except the string of shell money he had worn round his neck, which lay above, half hidden in the sand. But now there came down to the shore two beautiful girls. They walked along by the edge of the waves, and one of them saw the shell money. They dug and found his body, and laid it on the sand, bewailing the death of such a fine young man. After a time they went back to their village and told the priest. The old man gave them two dracaena leaves, on which he breathed, saying a charm. "One of these," said he, "will restore to life and one will kill." The two girls returned with the dracaena leaves to the corpse on the sand, and first tried the leaf which killed. This had no effect on the dead man. They then touched him with the other leaf. He opened one eye. They struck him with it. He lifted an arm. They did so again. He lifted a leg. They did so once more, and he stood up on his feet, a living man. The girls had their dog with them, so they said to the stranger, "See if you can race the dog to that tree." He tried to, but there was no strength in his limbs, and the dog won. They struck him again with

1 The Melanesians, p. 365. 
the dracaena leaf, and this time he got first to the tree. Then the girls gave him a green coconut to drink from, but he was sick. They used the dracaena leaf again, and he drank. So it was with the eating of yams and taro. At first he could not eat without being sick, but with the help of the charmed dracaena leaf he became sound and whole. Then they took him up to their garden and sat talking, loath to leave him. At last he said, "Have you no house work to do?" "Yes," they replied, "we must go back to the village, but we will meet you again here." They went home, and he took his way to the canoe-house, where the men of the place were secluded for bonito fishing, but there was no one there but one lame boy, all the rest being away fishing. So Taraematawa said to the lame boy, "Let us take this canoe and go after bonito." But the lame boy replied, "That canoe is forbidden." However, he persuaded him, and they went. When they had put to sea, Taraematawa asked for a hook, but the lame boy had none, so Taraematawa took out a dog's tooth and pretended to fish with that, to the amusement of his companion. Fishing with two rods, one in each hand, Taraematawa caught two fine bonito, and they returned to the canoe-house. He told the lame boy to climb for coconuts, and gave him a piece of soft wood to husk them with, so as to keep him employed for some time, and then he went off to see his friends in their garden. When the fishers came back empty-handed they stared in surprise at the two bonito, but the lame boy took all the credit for catching them. "There were plenty close in to the shore," said he; "you went too far out." They looked doubtful, but after a time went out again in their canoes. Taraematawa appeared again when they had gone, and he and the lame boy went out as before, this time taking the chief's canoe, and Taraematawa caught four bonito, which they put in the canoe-house. The same thing happened as before, but this time the fishers could not believe the lame boy, and, unknown to him, they left a watcher on shore when they went, and the watcher saw Taraematawa go out with the lame boy and catch five fine bonito. Taraematawa, on his return from the garden, disclosed himself to them, and next day was the great feast in the village to mark the conclusion of the maraufu, fine mats being laid all along the path from the canoehouse to the village, since none of the secluded men must set foot to the ground. While they were all feasting Taraematawa suddenly heard the sound of the winding of a conch far off. "The sound," said he, "is like that of my own conch at home in my big canoe," and cries with grief, but the people have heard nothing. It came nearer, only three or four miles away, and they all heard it. Nearer and nearer came the sound, and they saw the canoes, and the people in them called out, "Have you seen Taraematawa?" for they were his people. "Here he is," answered the people on the shore. The two girls began to weep at the thought of the departure of their guest, but their father said, "You shall go with him too." So they dried their eyes, and their father loaded Taraematawa's canoe with shell money, hanging it on the bow of the canoe till the bow sank and the stern rose up in the air. Then Taraematawa and his two beautiful wives embarked and set out for his home, where they lived together. 
Waipuamaremare.-He was the elder of two brothers. His younger brother went one day to a stream near the village, and found a bunch of pua (areca nuts) floating down with the water. He took it and carried it into the house, and leaving it in his bag he went out again. Presently Waipua came in and asked for some puc, but no one had any to give him. However, someone said, "There are some nuts in your brother's bag over there, which he has just brought lack from the stream." So he took it and began to tamu (chew areca nut, leaves and lime) and used it all up. Presently his brother came in again and asked where his areca nuts were, and when he learnt that they were all eaten he began to cry. Nothing would console him. Waipua put strings of shell money round his neck and gave him presents, but he only cried the more for his areca nut, so at last Waipua said "Well, don't cry, I will follow the stream till I come to the tree itself from which your nuts came." So he took his spear and club and bow and arrows and set out to look for the tree. After a time he came to an areca nut tree standing by the brink of the stream, but the nuts were not quite the same, so he went on. Presently he came to another areca nut tree, but again the nuts were not quite like those his brother had found, so he went on again. Night came on and he slept by the stream and went on again next day, but it was well on into the afternoon before he reached the tree he was seeking. He saw some fine branches, so he climbed up, but just as he stretched out his hand to pluck them, the tree lengthened and they were high above his head once more. This happened again and again till he was almost crying with vexation, but he was determined not to give in. At last he noticed the branch of a banyan which almost reached him, and he thought if he stood on the branch he would then be able to grasp the bunch of areca nuts, so he stepped on to the branch; but as he did so the areca nut tree sank down away from him, and sank lower and lower out of sight, and there he was perched upon the bough of a large banyan in another country, the country of the sky. He sat there wondering what he should do, and presently he saw two very beautiful girls come down to the stream to draw water, but instead of a bamboo they carried the skull of a dead man. Suddenly they saw his shadow in the water and started, thinking it was a man, but he moved and they did not look up. Then he dropped some leaves he was chewing, and the two girls saw the leaves floating by and wondered how they came there. Then he dropped a piece of areca nut and finally some of the red juice from his mouth. "It must be a bird," said they, and looked up and saw Waipua sitting on the bough of the banyan. "You are a ghost," said they. "No," said he, "but you are certainly ghosts; no one else would use a skull, we don't do such a thing in my country."

However, he came down, and they took him home to their village, but left him outside in an enclosure, and went and told their father and mother to go out to the enclosure and see the thing they had found. So their father and mother went to look and found Waipua all decked out in his bravest ornaments, shell necklaces, and shell armlets, and a flower in his hair, and they were delighted with him and brought hirn in and scolded their daughters for leaving this fine fellow outside. 
After a time the father and mother went away, but before going they said to their daughters: "Be very careful not to lift the stone so that he looks down and sees his home and desires to return to it"; but Waipua heard their words, and when they were gone he asked the girls what their parents had said to them. "Oh," said they, "they only told us to stay at home and cook"; but he shook his head and said, "No, that was not what they said." "Well," said the girls, "if you must know, they told us to go to the garden and get coconuts." "No," said he, "they said something else." So at last they told him, and he persuaded them to lift the stone, and when the three had lifted it, he looked down and saw his own country down below him, and a great longing seized him to return to his home. So for four long days the three of them collected strong lengths of rattan and made a small platform, and sat on it, and let it down by the four corners, through the hole. They let themselves down and down, but it was a long way and night came on, so they tied up for the night and slept. Next morning they went on again and reached the ground. But there was no longer a house where the village had been, for after his death the people had scattered far and wide, and the trees had grown up in the village, and the houses had rotted away. So they made a new one, and when the new village was finished they made a great feast, and there were great rejoicings. And there Waipua lived happily with his two wives.

\section{Ataro.-2. Spivits.}

All the ataro so far described have been ghosts, but there are many ataro which are spirits, i.e. they have never been men. There are three chief divisions of these: (1) Ataro ni matawa, sea spirits; (2) Ataro hasimou, woodland spirits; and (3) Ataro here or haaheu, the grasping or changing ataro. Besides these there are a few other special ones.

1. Ataro ni matuwa.-Matawa means the open sea or the horizon. These spirits of the sea are a favourite subject for San Cristoval artists. They are represented as partly human, partly fish-like.

In a paper contributed to the Royal Society of Victoria in 1879, called "Notes on the Customs of Mota, Banks Islands," Dr. Codrington gives a drawing of such a being, which is described as " a Tamate (Ghost or Dead Man) of the Sea-Facsimile of the original drawing by a native of Mota, Banks Islanas," and in the notes he writes: "Some of them (the ghosts) frequent the sea and do mischief there as their fellows do on shore. They are supposed to be malevolent towards the living. The accompanying sketch, which was made by a native, represents one of the seafrequenting ghosts-in the language of books, spirits of the sea. To represent them as belonging to the sea, or because the natives suppose them to have suffered a sea change, they are drawn as much like fishes as may be. These and the landhaunting ghosts appear in travellers' and anthropologists' writings as spirits of the sea, the woods, the rivers, etc., but the natives call them all tamate, which is simply dead men." The whole of this was no doubt simply a mistake, and is partly corrected 
in The Melanesians, where the same drawing, appears correctly described as to locality, "A Sea Ghost, San Cristoval, Solomon Islands," but the mistake of regarding it as a ghost remains. The paper is only mentioned lest it should be supposed that such beings are known in the Banks Group and are there called tamate. The nearest approach to them in Mota seems to be a being represented with a bird's head and a body banded like a variegated sea-snake and called a tamate. But it should be observed that though the word tamate means etymologically " dead " or " a dead man," the Banks Islanders believe in tamate which were never men, as we shall show later. To return to San Cristoval, these ataro ni matava are not ghosts but spirits.

They are thought to live far out to sea or near small islands along the coast. The chief of them is called Ngoriaru. He is known by this name in South Mwala, Ulawa, and all over San Cristoval. Two subordinate chiefs are named Huaholai matawa and Hanai matawa in Ulawa. Prayers are made to Ngoriaru when people embark on a voyage and sacrifices offered to him. Ataro ni matawa are malevolent beings. They shoot men with flying-fish. A man fishing in his canoe will feel a sudden pain in his back or neck and the bone will be broken. He will return to the village and ask the priest what has affected him and will be told after inquiry that he has been shot by an ataro ni matawa. Men learn dances from them. In a dream the soul goes out to the sea and is conducted by an ataro ni matawa to a sandy beach where in the surf the drowned people of Hanua asi are dancing. The soul goes night by night and learns the dance. The ataro ni matawa move in waterspouts, and the rainbow is their path. One who lives in the rainbow is worshipped at Ugi. A rainbow is always a sign for people to go indoors, not only because ataro ni matawa use it, but because it is a favourite bridge for other ataro as well. The soul of a man may use it to go afar while the body sleeps. Woodland ataro use it. If a man points at it with his finger, the finger is bent and can never be straightened again. A Heuru boy named Maeraha played out of doors when a rainbow was shining and his soul was seized by a wandering ataro. His body grew weaker and weaker till other ataro were called in by the priest to 'his aid. One sees an ataro ni matawa on his journeys as a wandering fire, or if one fails to see him, one smells a fish-like smell, a sign that he is near.

We give drawings of Tararamanu and Rakerakemanu, two famous ataro ni matawa, known along the north-east coast, and also of Wakatarau on the opposite coast (pp. 176-7). The last named lives at an island called Goroa. Some time ago he devoured two brothers who lived on the mainland opposite his island. He came up from the sea, changed himself into a cloud and came and rested on a stone on the shore. The two brothers came from a place called Rangi, where all had lately died. One was standing idly outside his house in the cool of evening, when he noticed the cloud on the stone. He called to his brother to come out and see it and asked him what he thought it was. "It is only a cloud of sunset," replied his brother. It came up from off the stone towards them and they fled into their house, and barred their door against him. They heard him come up close and 
stamp against the wall. Then he climbed up on the roof, looked down and saw them, broke his way in, and devoured them both.

Tararamanu.-Maekasia of Fagani describes as follows the beginning of the cult of the sea spirit Tararamanu :-

"Tararamanu is a true spirit of the open sea, he has no home on shore to which he belongs. Now this was the time of which I am telling when people first began to make a shrine for him, when he appeared to some men who were chasing bonito. There were three brothers, comrades, whose names were Waisi, Gaumafa and Fagarafe. They were living in the village and made a canoe for bonito fishing and they got their canoe ready, and all that belongs to such a canoe, fishing lines and tortoise

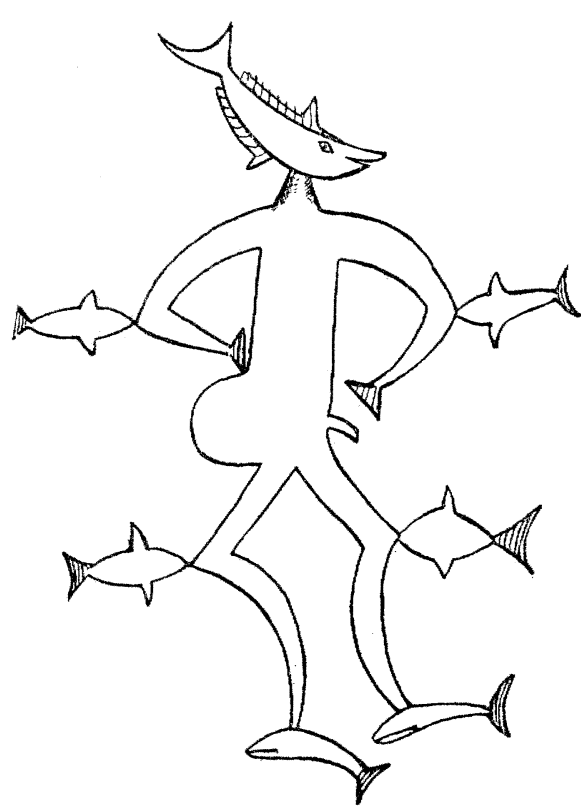

WAKATARAU.

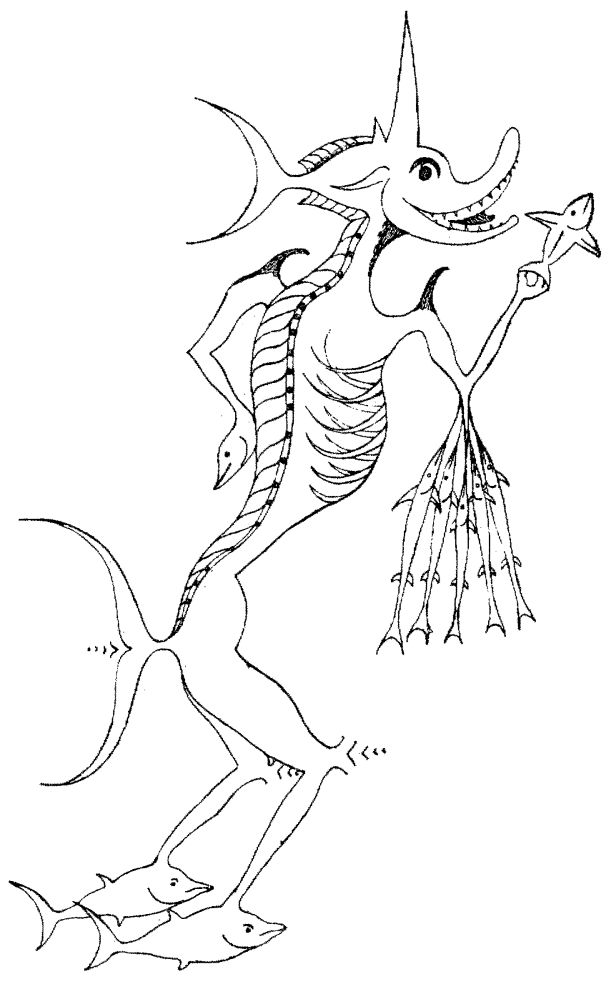

TARARAMANU.

Ataro ni Matawa.

(Drawn by Saunitiku, Fagani.)

hooks, both large and small ones. Then they hired from a chief named Pairi a bamboo fishing rod to fish with from the stern, and Pairi gave them two lengths and said to them, 'Friends, the name of this rod for which you are giving me money is Wakio' (the bird Wango people call Aragau), a bird that darts down swiftly on the fish beneath it. Gaumafa replied, 'It shall be the name of our bonito canoe, we will call it Wakio.' They often went fishing for bonito in the Wakio and sometimes caught three and four and five fish, but no more than that. One day they 


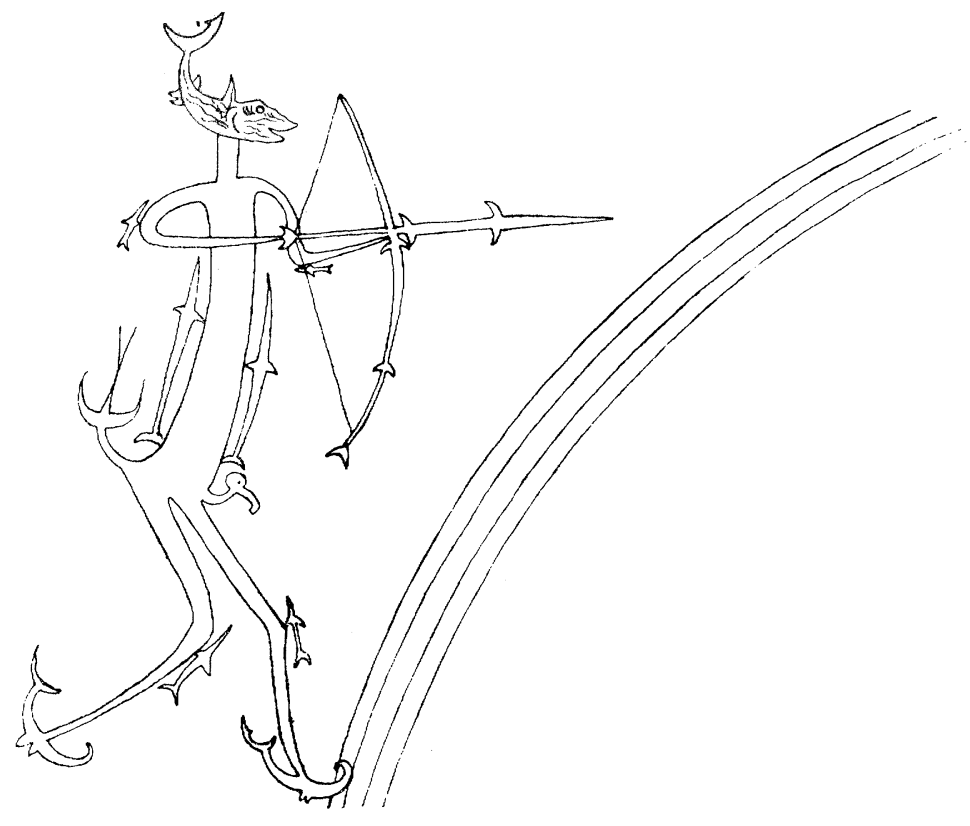

TARARAMANU.

(Drawn by Wataroto, Rafurafu.)

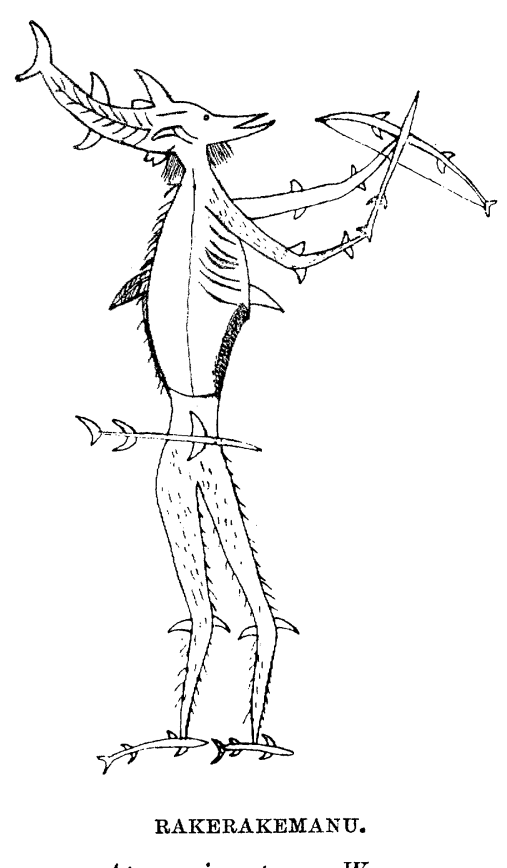

Ataro ni matawa, Wango.

(Drawn by Oroaniia, Wango.)

VOL. XLV. 
went out, and paddling towards the open sea they failed to find the shoal of big bonito, though they kept dipping their rod into the water, but they did not get a single bite with large or small hooks; however they let their canoe float on and on towards the open sea far from land. Then looking towards Ugi they saw a red rainbow right across Ugi, like a piece of scarlet cloth, crosswise against the island as one pulls up a sail, and they were afraid that something would happen to them. 'No doubt,' they said to one another, 'some spirit of the open sea will presently shoot at us.' The red rainbow faded and was followed by a grey drizzle of rain, and when this lifted and the sun shone brightly on them they saw far off a streak of white, like a peeled tree standing out white in the forest, but this stretched across the horizon, flashing swiftly along like a spreading fire, the foaming path of bonito, rushing and leaping on the small fish for their prey. What were they like? like monstrous things! for Tararamanu had already come down in the red rainbow and the grey drizzle of rain, and the bright sky afterwards, and heit was who drove towards them the eating bonito, towards the men who had been seeking bonito in the open sea far from shore, and now he began to give them bonito three and four and five and six, and the bonito shoal contained a hundred or perhaps more than two hundred of them, so that their canoe was already almost sinking. Then he possessed Waisi and spoke with Waisi's voice to the other two, saying, "You call your canoe "The Wakio," call it so no longer, but call it after my canoe "Sautatare-i-roburo," " $\mathrm{He}$ who follows up the bonito to their home," and make me a shrine in it and I will give you fi-h in it and sacrifice to me both in the sea and in the village shrine.' So that was the beginning of it and these are the very words spoken in the beginning to the people who worship him and knew him well, so that he gave them bonito and they sacrificed to him some of the fish which they caught, and the spirit Tararamanu gave them generously all kinds of fish, that is to those who worshipped him and prayed and sacrificed to him, but a man whom he disliked he killed. Such a one he would shoot with his bow and arrow, the arrow one of those garfish which comes skimming over the surface of the sea and then suddenly dives down alongside one, this is a fish a spirit has shot at one. There are two characteristics of Tararamanu : if he gives he gives generously all sorts of fish, but then again he may attack one. This strange spirit of the open sea has two characters and is two, like two men who are fast friends and have but one name. But his cult was dying away at Fagani before the day came when Christianity was introduced; men did not seek him because they were afraid of him."

2. Ataro hasimou, i.e. bush ataro, correspond on land to the ataro ni matawa in the sea. They are spirits, not ghosts, and they are malevolent. But it is sometimes difficult to say in a particular case whether it is an ataro hasimou or an ordinary ataro that is spoken of: the natives themselves are sometimes uncertain. It is possible, for example, that Wowotagai mentioned above is really an ataro hasimou, a spirit, not a ghost, and Tapia, of whom we shall write presently, is possibly a ghost, though probably a spirit. Again there is manifest confusion as to whether the being connected with a certain tree, pool or rock is a figona or an ataro hasimou. 
Native opinion is uncertain. And finally there is confusion between ataro hasimou and kakangora, the little people to be described later. All ataro hasimou have straight long hair, unlike Melanesians, described as like the hair of Polynesians. They are about at the shining of a rainbow, in a sunshower, and during heavy rain when everything is grey and half hidden. There are certain trees where they are known to dwell like the uri in the tale of Hasihonu. They are found at particular rocks or pools. Children are warned not to go near these places. The result would be the stealing of the child's soul, his body would waste away. Should such a thing happen, the priest is called in to obtain the help of the ghosts. Ghosts are stronger than woodland spirits, and can recover from them the souls they have seized. The natives going through the bush at night hear a crackling and rustling near the path. It is an ataro. If the traveller calls out to it to go away and it does so, he knows it must be a ghost, not malevolent, like an ataro hasimou, which would not go when asked to. Ataro hasimou are not sociable like ghosts, and refuse to chat when met with. The mere sight of one is enough to make a man waste away and die. They do not decorate themselves with ornaments. They are less powerful than ghosts. Sorne of them live underground.

There is one near Pamua at a spring called Pupu. This ataro lives underground. A native friend of ours, named Mamake, recently saw it. It was about three feet high, a woman, with long straight hair down to her knees, dark skinned and speechless. It was during a steady downpour of rain that he passed by and saw her. Her head, like that of an ataro here, was fixed the wronc way, her face towards her back. He ran home and was none the worse, but he tells us a friend of his saw her some time ago, and when he got back blool flowed from his mouth, nose and eirrs, till he died.

Tapra, known along the northern cnast of San Cristoval, is probably an ataro hasimou. Ur. Coulrington, who considered all ataro to be ghosts, wrote of him as "a malignant ghost, who seized a man's soul and bound it to a banyan," when a sacrifice of substitution was offered, so that the man, who was wasting away, might recover. Tapia's priest burnt pig or fish on the sacred stone.

Maekasia of Fagani writes as follows of Tapia:-He is either a ghost or a spirit. He can change himself into a man or woman; he has no pity, and only searches for men to destroy them; he properly belongs to the eastern part of the island Kahua and Rumatari and beyond, but our fathers at Fagani also worshipped him and sacrificed to him on the black rock at the mouth of the river near Tomare, on the little hill Qarusunafau. There they sacrificed to him the fat of pigs for a burnt offering and sweet savour ; his nature was to destroy men, and he was utterly without pity. But in the end he married a woman, and was kind to her, doing her no injury, until the day when she died of a sickness. She was the wife of Tapia's priest, so that she had two husbands, the priest and Tapia. She knew that Tapia came into her and stayed with her, and she would say, "Tapia came to me to-day and stayed with me." Often and often he came and stayed with her and did her no harm. 
In the following tale told by Bo, the old chief of Heuru, to his son Takibaina, an ataro hasinou, named Warungarae, takes the form of a man's wife to deceive him, and goes off with him in his canoe, destroying him. The wife, left desolate, is saved by a ghost, in the shape of a turtle; at least it is probably a ghost, though it may possibly be a family guardian spirit.

Warungare.-Two people were married; the name of the man was Bworouharimamu and the name of his wife was Saumamaruitaaru. They lived in their village by the shore. When Saumamaruitaaru was about to bear a child, they went for a walk along the sand, and they saw a large fruit of the uri (Spondias dulcis), ${ }^{1}$ which the current had carried out from the neighbouring river and the sea had washed up on the beach; and they took it and asked one another whence it could have come. So they carried down their canoe, launched it through the surf, and paddled along the coast till they came to the mouth of the river, which they turned. Bworouharimamu told his wife Saumamaruitaaru to cover up carefully her body and said to her, "When we land we will go to this side of the $u r i$, the side nearest us, and don't you go in to the farther side; and when there is a sunshower we must hurry into our canoe." So they went along gathering the fruit, but the woman wandered away to the farther side of the tree under an overhanging branch. Then the woodland spirit became changed again and came down from the tree, and then there was a sunshower, and the spirit took the form of the woman. The name of the spirit (ataro) was Warungarae. Then the spirit said to the man, "Come, jump quickly into the canoe with me or Warungarae will see us and devour us." So they embarked, Warungarae first and then Bworouharimamu, who took the steering paddle, and they paddled away down the river, And now Saumamaruitaaru came back from the farther side of the tree and saw her husband and the spirit paddling away and already some distance off. She began shouting and calling out to her husband, "Here am I, here am I, it's I myself, but that is the evil spirit you are carrying off with you in your canoe." But the spirit said to him, "Ah! what a clever deceiver, that is the evil spirit himself all the time ; paddle hard or he will devour us both." It was all in vain that his wife shouted herself hoarse on the bank, for neither of them paid any further attention to her, but paddled on along the edge of the harbour till they were lost to sight.

So she climbed up a tall daro tree, whose branches bent down over the water, and made her way along them. Then she untied the necklace of fish teeth which she wore round her neck, and unstrung it. She took off one of the teeth and threw it down into the water, and all the fish of the sea rose up and came to her. "No," she said, "I can't go with any of you, for soon, perhaps, you will be pursuing your prey and will throw me off, without troubling about me; you will never think of me, you will be sure to lose me." So then she threw down into the water another tooth from her necklace, and all the sharks rose up and came to her.

1 The fruit which the Uraua clan are forbidden to carry. 
But she said to them, "No, I dare not trust myself to you, for presently, perhaps, you will be chasing some canoe, and you will throw me away, without troubling what becomes of me." And so with the next tooth, she spoke the same words as before. At length there was only one tooth left, the very last tooth of all, but she threw it down into the water and up rose the turtles, for it was a turtle's tooth. Then she said, "Good, now I can jump down safely," for she called the turtle her ancestor. So she sprang down from the overhanging branch of the daro tree on to the back of the turtle, whose name was Hasihonueero, and there she crouched. The turtle dived down with her and took her right out to the open sea. Then she (the turtle) dived again, down and down, till the woman on her back felt as though she must die for lack of breath, but they came up safely again to the surface of the sea. Then the turtle took a long breath, and leaving the woman at the surface, went down and down to the bottom and brought stones to make a place for the woman to walk about on. When she had brought four or five and saw that they nearly reached to the surface of the sea, she brought the woman there, but the water still reached to her throat. Then the turtle brought some more and piled them up on the island and they very nearly reached to the surface, the water now came to her armpits. She brought four or five more and the water came to her breast; four or five more and the water only came to her waist. So she stood there while the turtle went for a few more, till the water came to her knees and then only to her ankles. And at last, when the turtle had brought some more stones the place was dry, above the waves: it was an island.

The woman walked about on it, but as yet there were no trees on it, and said to herself, "Yes, it has indeed become an island, this work of my ancestor, but still there are no trees on it." And then at the sound of her speaking, trees sprouted from the ground, and the grass and fruits good to eat--breadfruit and almonds, Barringtonia nuts and coconuts, food of all kinds, yams, both smooth and prickly, and taro. Then the woman said to herself, "Yes, now indeed there are all sorts of food for me to eat, but still there is no fire," whereupon the turtle who had befriended her, came to the shore of the island and said to her, "Choose out a flat piece of shell from my back and make with it a house for yourself, and as for that other thing you desire, rub on the shell till a spark comes." And so she did, and there she lived. At length she bore the child, whom she was expecting when she and her husband set out in their canoe, and she took him joyfully in her arms and brought him to the turtle to nurse, and said to her, "Grandmother, you must nurse my child for awhile." So the turtle came and set him firmly on her back, and carried him off far out to sea.

3. Ataro here.-This is the general name for this spirit ataro, but it is also known as haaheu, or "changeling," in Ulawa (as well as akalo hele), and on the south coast of San Cristoval as ataro ngaungau, devouring ataro, or ataro maramara inuni. It takes the form of a man or woman, appearing at daybreak or at dusk. To a man it takes the form of a beautiful woman, tempting him to go with her and eat with her. It is generally the form of some woman known to 
him, but gorgeously decorated. If a woman sees the ataro here, she sees it as some man she knows.

The chief point of interest with regard to the ataro here is the widespread belief in it, in Polynesia as well as in Melanesia.

There is a good account of an ataro here in Robert Louis Stevenson's Beach of Falesa, so no doubt the story is current in Samoa.

In the Polynesian Reef Islands this spirit is called atua fafine. The atua fafine appears usually at dusk on the rocks, to a man in the form of his wife, to a woman in the form of her husband. It has red hair and a red throat. If he says to the atuc, "My wife!" the man dies.

Another account from these Polynesian Reefs makes the cutuc fafine appear as two women joined together like the Siamese twins. They follow a man walking alone at dusk. They are fair and ruddy and sometimes accompanied by two lightcoloured men. A man was one day followed by these handsome women, and accepted from them a wild coconut, of which he ate a portion. "Now," said the atua, " he is already one of us, we have him for certain." He reached the village, was sick, and "died," i.e., he became unconscious, but recovered by the application to his nostrils of a certain sweet-smelling leaf.

Besides the ataro spirits there are other ataro, some of whom were certainly spirits and others probably so. A certain ataro presided over Rotomana, the abode of the dead; another guarded the entrance; both were spirits.

The rainbow has been several times mentioned as the path of ataro. Maekasia, of Fagani, says "it was the great road of the spirits of the sea; if people saw a rainbow they thought there was a spirit coming towards them along it, and this is why they were so afraid of it. Even now when they see a rainbow they all run into their houses."

"A turtle," he adds, "holds up a rock at Haununu. He knows when án earthquake occurs, hurries to the stone, and clasps it. They think if that turtle should fail to do so and did not clasp the rock, then that would be the end of the island, but because he looks after the rock the island still stands. They think that rock is the supporting pillar of this island of San Cristoval, and they say of the turtle that if he had not attended to that rock the island would have already sunk and been destroyed in the sea."

This turtle is famous everywhere in San Cristoval, and is often said to have a bird's head. It is represented by native drawings on the posts of the serpent house at Haununu. The name Haununu means earthquake-rock. It is not a ghost, of course, but we do not know whether it is called an ataro.

Maekasia writes of meteors that " the people think falling stars also are ataro and we call them Ataro tari-wandering ataro-and the heathen used to be very much afraid of them when they saw them, thinking it was an ataro coming down. They used to run into their houses and bar the doors." Perhaps these were ghosts: Fireflies at evening were spoken of as souls of the dead, but Ataro ni matawa, who were not ghosts, were seen as wandering fires. 
The guardian spirits of families, not clans, are also called ataro, but are not considered to be ghosts. These were in the form of animals. Each family has its guardian animal, and a man inherits this from his father, and it continues to guard his son. This, then, is a case of inheritance from the father, and it should be noted that, though a spirit, the animal is called ataro, not figona. The only other case of such inheritance we have mentioned is that of the priest of the hare ni asi, the shrine for ghost worship, who inherits from his father and passes on to his son, but the son may be adopted or bought. These two cases of inheritance from the father are connected with ataro beliefs. A boy ordinarily inherits from his mother's brother.

The guardian animal is very often a snake, sometimes an opossum, either a hito or a kunu, and often a frog. Its haunt is known. It comes to the house from time to time when any event of importance occurs, such as a birth or death in the family, or a case of sickness. It is fed and thought to have a connection with the family. Sau's father, when he became a Christian, was horrified to discover that, as he supposed, his family had always been specially connected with the Evil Spirit, since his family guardian took the form of a snake.

The following is Dr. Codrington's account of the aiaro here in the New Hebrides :-

"Beings called Tavogivogi must be classed as spirits; they are certainly not human beings, and correspond to the mysterious snakes called mae, which in neighbouring islands are believed to assume the form of men. A Tavogivogi is not thought ever to have the appearance of a snake; one of them appears in the form of a youth or woman, in order to entice one of the opposite sex, and the young man or woman who yields to the seduction dies. . . . The young man goes home and sickens; he remembers the sudden disappearance (like a bird), knows what has befallen him, and never recovers. The name means ' changeling,' from the word in the Banks Islands wog, to change the form.

"The belief is most strong in all these islands (Banks and Northern New Hebrides) that the snake (called mae, a banded sea snake) turns itself into a young man or woman-generally into a young woman - to tempt one of the opposite sex ; to yield to the temptation causes death.

"It is possible to discover the deceit, but the discovery is often made too late. . . . In the Banks Islands a young man, as one has related his experience to myself, coming back from his fishing on the rocks towards sunset, will see a girl with her head bedecked with flowers beckoning to him from the slope of the cliff up which his path is leading him; he recognises the countenance of some girl of his own or a neighbouring village, he stands and hesitates, and thinks she must be a mae; he looks more closely, and observes that her elbows and knees bend the wrong way; this reveals her true character, and he flies. . . . At Gaua, Santa Maria, a man met one of these standing or variegated snakes as they call then, mae tircatira, valeleas, on the beach at night in the form of a woman of the place. Seeing by her reversed joints what she was, he offered to go to the village and bring her 
money. When he returned he found her waiting for him in her proper form, as a mae; he scattered money upon her back, and she went off with it into the sea."

One of us well remembers the excitement caused by a mae, seen at Mota one evening by a man of the place ten years ago. We were sitting talking in the village, when this man rushed up the path from the landing-place in great excitement, declaring he had seen a mae valeleas. We immediately repaired to the spot on the cliff where the mae had been seen, but found nothing. The man saw the mae in the form of a woman of the village named Mary. She sat by the path, and he spoke to her and said, "Shall we go up to the village?" "Not I," she replied, "you go up by yourself." He then looked closely at her and saw she had decorated her hair with two kinds of hibiscus, red and white, which no native woman would think of doing. He recognized her as a mae. The real Mary was sitting with us in the village. Nothing happened to the man.

The same thing exactly is known in San Cristoval, and natives declare that many deaths are caused in this way. It is worth while observing that, though the Banks Island appearance is not a ghost, and no one supposes it to be so, yet they call it a tamate. It seems hard to believe they would use this term for it unless it were a foreign belief, it would certainly be called a vui. The following are interesting facts regarding this ataro, showing how details vary in different islands with the same underlying idea.

1. There is always a change, generally into an animal.

In the New Hebrides the beautiful woman changes into a bird.

In Santa Maria (Banks Islands) into the stalk of a creeper.

In other parts of the Banks Islands into an amphibious snake.

In San Cristoval into a brush turkey ; also in Mwala.

In Ulawa it turns into a butterfly.

In the Polynesian Islands, referred to above, no change is mentioned.

2. If you see the change you die. This seems to be everywhere the case. Generally also if you eat food offered to you, you die. In some places, as in San Cristoval, if you can understand what it says to you, you die.

3. It is not quite human. Everywhere the joints are reversed.

In the Polynesian Reef Islands it has a red throat.

In the Banks Islands the skin at the back of the neck is snake skin, and the creature has a bright red tongue.

In San Cristoval and Mwala the head is reversed as well as the joints.

4. It does not understand human conditions, and there is sure to be something it does not know how to do, by which it may be detected for what it is. This is very characteristic. ${ }^{1}$

In the New Hebrides, ask it the name of some common tree, and it cannot

1 These and other characteristics seem to show that it belongs to an introduced foreign cult. Every man of the place knows the nature of a nettle; not so foreigners, as Englishmen in the Islands have several times proved. 
tell you. Here, too, you may ask it to sit on a nettle, and its ready compliance betrays it.

In the Polynesian Reef Islands it is known if you offer it a drink from a coconut cup : it doesn't understand drinking, and holds the cup upside down. Or you may give it a twig to break, and the creature holds it aimlessly, wondering how to break it. It does not understand the use of areca nut.

In San Cristoval you may ask it where the sun rises: it will be thrown into confusion and point all round the compass; or you may throw a spear at it and see whether it knows enough to jump aside.

5. In its attempt to entice it overdoes things, from ignorance of local customs.

In the New Hebrides it blackens its hair, if a man, and powders its hair white, if a woman; but always in excess of what is proper.

In the Banks Islands the tatoo marks are of so gorgeous a pattern as no mortal skill could fashion. It puts more hibiscus flowers into its hair than men do; or mixes the colours, which native women never do.

In San Cristoval and Mwala it is beautifully tatooed and has more rings, and finer ones, than living men and women.

6. It may be charmed by the application of sacred leaves. In the Banks Islands it cannot even bear the sight of a white amaranthus flower, and if you strike it with a croton leaf its tail starts out. A dracaena leaf is equally efficacious in San Cristoval.

7. It never appears at any time except in the morning or evening; and always by the shore.

In Ulawa it is thought that there are really only two, a male named Pwaai, who always takes the form of a man to appear to women, and a female, his wife, who undertakes the seduction of men and always appears as a woman. Everywhere in the Banks Islands as well as in San Cristoval, Mwala and Ulawa, it is much more usual for Pwaai's wife to be seen, than for Pwaai himself to appear.

(Continuation in next issue.) 